\title{
Direct ESR dating of the Pleistocene vertebrate assemblage from Khok Sung locality, Nakhon Ratchasima Province, Northeast Thailand
}

\author{
Mathieu Duval, Fang Fang, Kantapon Suraprasit, Jean-Jacques Jaeger, \\ Mouloud Benammi, Yaowalak Chaimanee, \\ Javier Iglesias Cibanal, and Rainer Grün
}

\begin{abstract}
We report here the first direct dating study of the faunal assemblage from Khok Sung locality, Thailand. This palaeontological site is of great biochronological, palaeoenvironmental and biogeographical significance. Firstly, it has yielded a rich and diversified Pleistocene vertebrate fauna with up to 15 mammalian species from 13 genera, 10 reptile species, as well as fish and bird remains. Interestingly, while most of the mainland Southeast Asian Pleistocene mammal fossils originate from cave deposits, the Khok Sung fossil layer is located within an $8 \mathrm{~m}$ thick fluvial terrace. Secondly, it is geographically located in an area of major importance for reconstructing the migration pathway of large mammals between South China and Java.

Combined US-ESR dating of five teeth provides two possible ages of $130 \pm 29 \mathrm{ka}$ and $217 \pm 36$ ka for the fossils. The reason for the occurrence of these two age groups lies in the fact that it was not possible to obtain sediments that were directly associated with the measured samples, nor was it possible to carry out in situ gamma dose rate measurements due to the high water level. Sediment samples recovered from museum specimens show significantly variable concentrations of radioelements. Both options are equally plausible, as independent methods did not provide firm evidence favouring one or the other age range. The results illustrate the intrinsic limitations of the ESR dating method when fossil teeth are not collected in situ during the excavation.

Regardless whether the age of the Khok Sung fauna corresponds to MIS 7 or early MIS5, it is nevertheless one of the oldest assemblages directly dated in the region. Further efforts are required for more accurate fossil identification and attribution and for additional numerical dating in this region to improve the biochronological framework of the Pleistocene mammalian faunas in Southeast Asia, which presently remains quite imprecise.
\end{abstract}

Duval, Mathieu, Fang, Fang, Suraprasit, Kantapon, Jaeger, Jean-Jacques, Benammi, Mouloud, Chaimanee, Yaowalak, Iglesias Cibanal, Javier, and Grün, Rainer. 2019. Direct ESR dating of the Pleistocene vertebrate assemblage from Khok Sung locality, Nakhon Ratchasima Province, Northeast Thailand. Palaeontologia Electronica 22.3.69 1-25. https://doi.org/10.26879/941 palaeo-electronica.org/content/2019/2794-esr-dating-of-khok-sung-site 
Mathieu Duval. Australian Research Centre for Human Evolution (ARCHE), Environmental Futures Research Institute, Griffith University, Nathan, QLD 4111, Australia.

Centro Nacional de Investigación sobre la Evolución Humana (CENIEH), 09002 Burgos, Spain.

m.duval@griffith.edu.au

Fang Fang. Research School of Earth Sciences, The Australian National University, Canberra ACT, 0200, Australia. Fang.Fang@anu.edu.au

Kantapon Suraprasit. Department of Geology, Faculty of Science, Chulalongkorn University, Bangkok 10330, Thailand. Kantapon.S@chula.ac.th

Jean-Jacques Jaeger. PALEVOPRIM, UMR CNRS 7262 INEE, University of Poitiers, 6 rue Michel Brunet, 86073 Poitiers, France. jaeger.jean.jacques@gmail.com

Mouloud Benammi. PALEVOPRIM, UMR CNRS 7262 INEE, University of Poitiers, 6 rue Michel Brunet, 86073 Poitiers, France. mouloud.benammi@univ-poitiers.fr

Yaowalak Chaimanee. PALEVOPRIM, UMR CNRS 7262 INEE, University of Poitiers, 6 rue Michel Brunet, 86073 Poitiers, France. yao.chaimanee@univ-poitiers.fr

Javier Iglesias Cibanal. Centro Nacional de Investigación sobre la Evolución Humana (CENIEH), 09002 Burgos, Spain. javier.iglesias@cenieh.es

Rainer Grün. Australian Research Centre for Human Evolution (ARCHE), Environmental Futures

Research Institute, Griffith University, Nathan, QLD 4111, Australia.

Research School of Earth Sciences, The Australian National University, Canberra ACT, 0200, Australia.

rainer.grun@griffith.edu.au

Keywords: Khok Sung; Southeast Asia, Thailand, Electron Spin Resonance (ESR) dating; fossil teeth; Ailuropoda-Stegodon

Submission: 9 November 2018. Acceptance: 3 October 2019.

\section{INTRODUCTION}

The Khok Sung fossiliferous layer was discovered during the digging of a water reservoir for a nearby factory. About 5-7 $\mathrm{m}$ below the top soil surface, a layer of organic rich sands was found to contain bone fragments, associated with teeth and jaws of fishes, reptiles and mammals. A one-month emergency excavation was subsequently organized in 2005 by the Department of Mineral Resources, Bangkok, in association with a French team of palaeontologists, within the framework of a joint Thai-French Palaeontological Research Project. This excavation led to the discovery of a rich Pleistocene vertebrate fauna originating from a fluvial terrace deposit associated to the Mun River (Chaimanee et al., 2005). A Middle to Late Pleistocene age was initially inferred from the study of the large mammal assemblage (Chaimanee et al., 2005), although the first mention of an age for the locality published in an international journal is Early Pleistocene (Martin et al., 2012). This initial biochronological assessment was confirmed by a subsequent magnetostratigraphic study of the deposits, which displayed a dominantly normal polarity (Suraprasit et al., 2015).

The multidisciplinary study of the fossil assemblage rapidly emphasised the biochronologi- cal, biogeographical and palaeoenvironmental significance of Khok Sung locality. In addition to the richness of the fossil assemblage, the site appears to be unique on many aspects. First, it is one of the very few open-air Pleistocene sites in Thailand and Southeast Asia, whereas the large majority of fossil assemblages has been identified in cave environments. Additionally, located at the interface between mainland Southeast Asia and Indonesian islands, Thailand holds a key position for the understanding of large mammal and human dispersals between these two distinct biogeographical areas (also named as Indochina and Sunda provinces) during the Pleistocene. Consequently, the study of the Thai palaeontological record is crucial for reconstructing migration pathways (e.g., SivaMalayan and Sino-Malayan routes) and testing the relevance of different hypotheses (e.g., the savannah corridor) regarding the environmental conditions favouring these dispersals (e.g., Bird et al., 2005; Louys and Meijaard, 2010; Suraprasit et al., 2016; Tougard, 2001). In particular, the savannah corridor hypothesis has been proposed to explain the dispersal from China to Sundaic subregion of several open grassland species, and especially that of Homo erectus, during the glacial periods of the Pleistocene. However, the large mammal Pleis- 
tocene record of Thailand remains overall poorly documented compared with that of other Southeast Asian countries, due to a combination of inappropriate taxonomic identifications, a lack of numerical dating studies and the limited number of fossil sites currently available (Suraprasit et al. 2016; Louys and Meijaard, 2010). This is why numerical dating results are urgently required to overcome at least one of these issues. Here, combined U-series and Electron Spin Resonance (ESR) dating method was directly applied to several fossil teeth collected from the fossiliferous level to cross-check and, perhaps, further constrain the previous chronological attribution of Khok Sung vertebrate assemblage.

\section{KHOK SUNG SITE}

\section{Geological and Stratigraphic Setting}

The Khok Sung locality is located at about 15 $\mathrm{km}$ north of Muang District in Nakhon Ratchasima Province and is close to the present-day Mun River (Figure 1). The area is a part of an uplifted tectonic unit, the Khorat Plateau, resulting from a fault block that was active during the mid-Tertiary to Quaternary (Songtham and Chaodumrong, 2014). The Khorat plateau corresponds to a continental sedimentary basin filled with Mesozoic to Quaternary sediments. The Khok Sung sedimentary sequence comprises of an $8 \mathrm{~m}$ thick terrace deposit containing a succession of layers of unconsolidated gravels, sand, silt, clay and mud, directly overlying nonmarine Mesozoic red beds. The stratigraphy of Khok Sung site can be subdivided into nine unconsolidated sedimentary units (Figure 2), named A to I from top to bottom (see Supplementary Material
Table S1 for detailed sedimentological data). All vertebrate fossils were found within unit $F$, an organic-rich, dark grey gravel and sand layer located about 5-7 $\mathrm{m}$ below the surface (Figure 2). In this unit, the coarse-grained sands are interbedded by some layered-silty mud lenses at their upper part, while the plant and vertebrate remains are abundant in the lowermost part (Suraprasit et al., 2015). All vertebrate fossils are likely contemporaneous due to the rapid deposition of sediments in the channel sequence (Duangkrayom et al., 2014).

\section{Faunal and Floral Assemblages}

The Khok Sung assemblage includes diverse groups of large vertebrates, as well as some invertebrate remains such as gastropod shells. The reptilian assemblage comprises testudines, a gharial, a crocodile and squamates, while fish remains were tentatively attributed to large silurids (Claude et al., 2011; Martin et al., 2012; Suraprasit et al., 2016). One vertebral fragment of an unidentified bird, but belonging to the order Galliformes, was also found (Suraprasit et al., 2016). The mammalian assemblage contains 15 species from 13 genera including extinct and extant large-sized taxa: a primate, carnivores, proboscideans, rhinoceroses, a suid, cervids and bovids (see Table 1 for the complete faunal list) (Suraprasit et al., 2016).

Plant remains included unaltered fruits, seeds, leaves, wood, tubers, amber, resins and pollens (Grote, 2007). The palaeobotanical study suggested the presence of tropical mixed deciduous and dry evergreen forests in the area (Grote, 2007). This interpretation should be considered
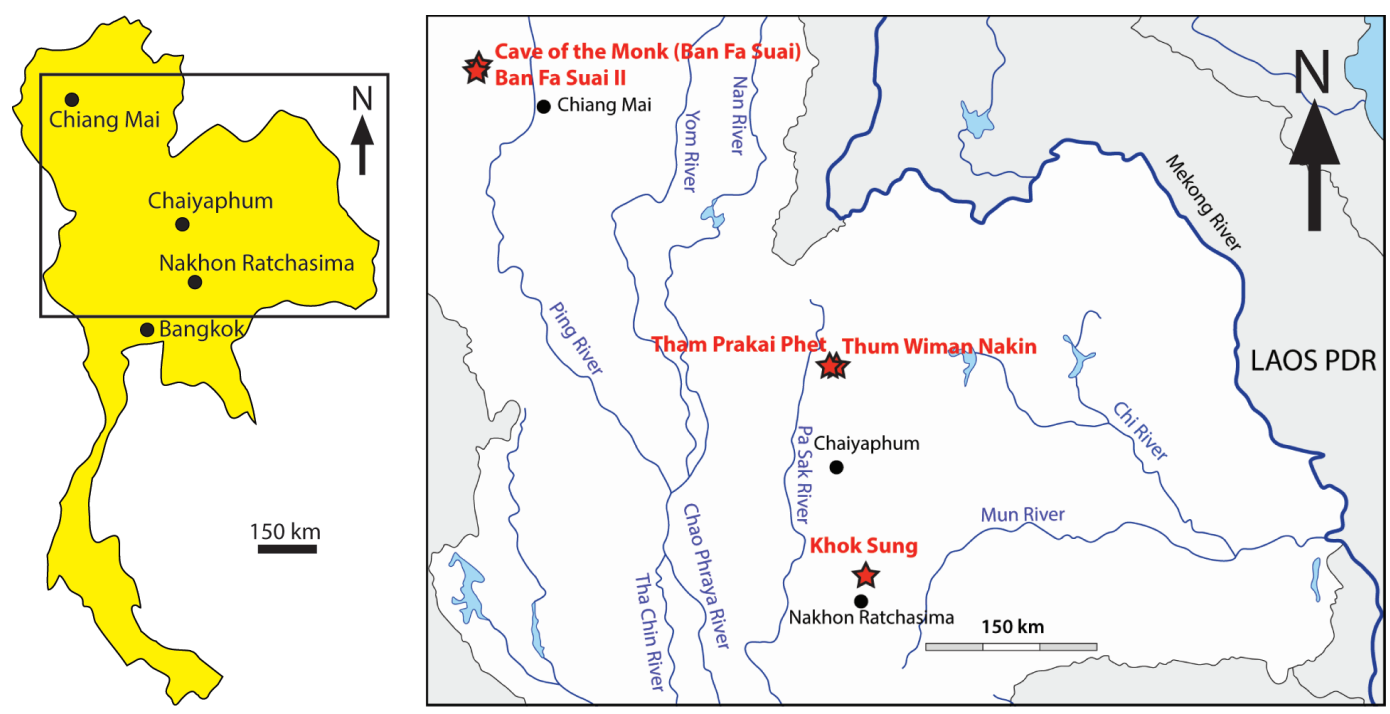

FIGURE 1. Map of Thailand showing fossil sites mentioned in the text (star). 


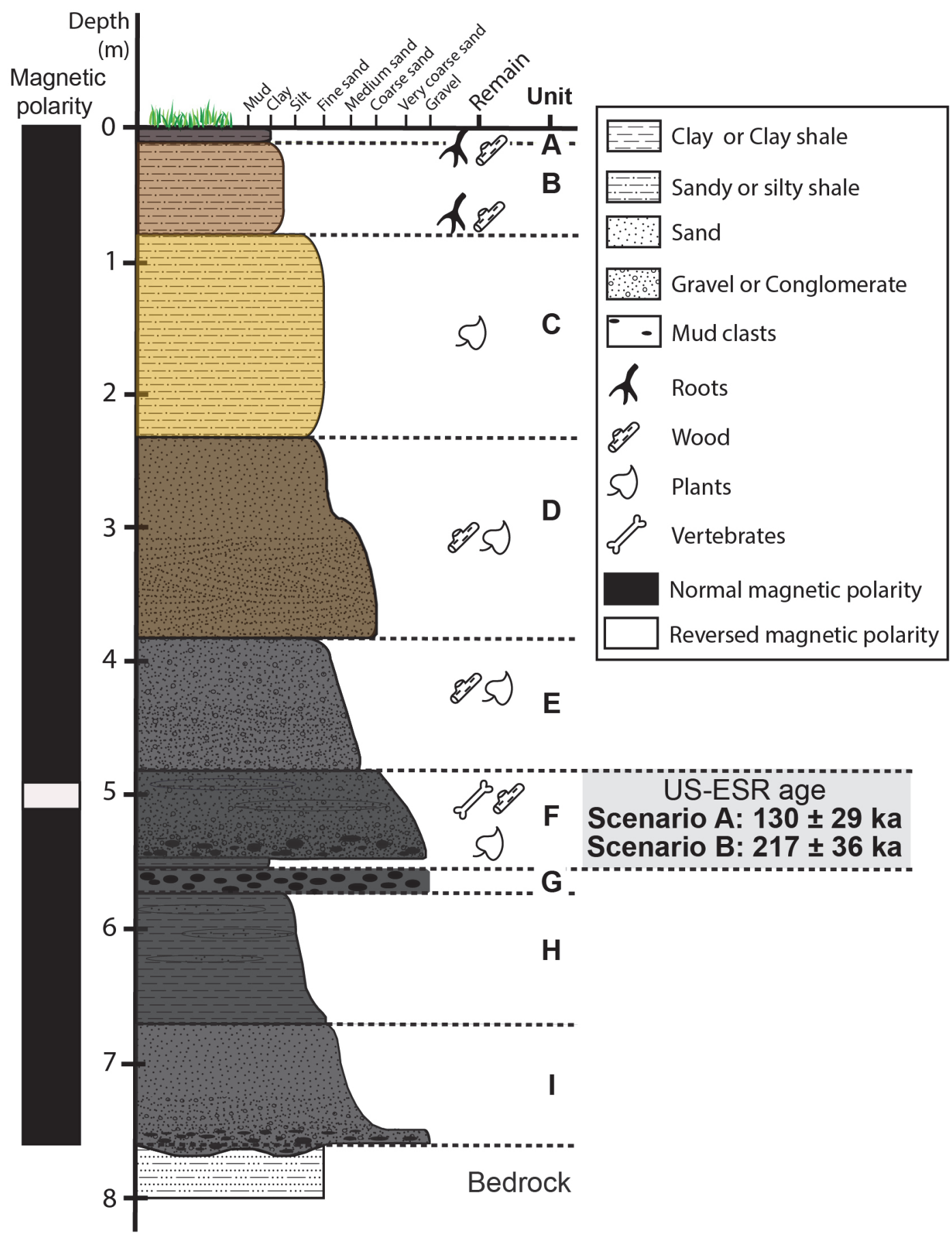

FIGURE 2. Magnetostratigraphic and lithostratigraphic sections of the Khok Sung sand pit, Nakhon Ratchasima Province (modified from Suraprasit et al., 2015).

with caution, as these elements do not seem to be entirely reliable proxies for palaeoenvironmental reconstructions (see discussion in Suraprasit et al., 2015).

\section{Palaeobiogeographic Significance of Khok Sung Fauna}

The Khok Sung fossil assemblage is of great importance for biogeography. It is located on a dispersal route between South China and Java and thus holds a significant key for reconstructing the southward migration pathway of large mammals 
TABLE 1. List of the Khok Sung vertebrate fauna [after Claude et al. (2011), Martin et al. (2012), Suraprasit et al. $(2015,2016)]$.

\begin{tabular}{lll}
\hline Class/ & Species \\
Order & Family & Spen \\
\hline
\end{tabular}

\section{Mammalia}

Proboscidea

Stegodontidae

Elephantidae

Perissodactyla

Rhinocerotidae

\begin{tabular}{|c|c|c|}
\hline & & Rhinoceros sondaicus \\
\hline & & Rhinoceros unicornis \\
\hline \multicolumn{3}{|c|}{ Artiodactyla } \\
\hline \multicolumn{3}{|c|}{ Bovidae } \\
\hline & & Bos sauveli \\
\hline & & Bos gaurus \\
\hline & & Bubalus arnee \\
\hline & & Capricornis sumatraensis \\
\hline \multicolumn{3}{|c|}{ Cervidae } \\
\hline & & Axis axis \\
\hline & & Rucervus eldii \\
\hline & & Rusa unicolor \\
\hline \multicolumn{3}{|c|}{ Suidae } \\
\hline & & Sus barbatus \\
\hline \multicolumn{3}{|l|}{ Primates } \\
\hline & Cercopithecidae & \\
\hline & & Macaca sp. \\
\hline \multicolumn{3}{|l|}{ Carnivora } \\
\hline \multicolumn{3}{|c|}{ Hyaenidae } \\
\hline & & Crocuta crocuta ultima \\
\hline \multicolumn{3}{|c|}{ Canidae } \\
\hline & & Cuon sp. \\
\hline
\end{tabular}

and its timing. Several dispersal events must have occurred during the Pleistocene (Suraprasit et al., 2019), such as that of the Homo erectus-Stegodon fauna, which was later replaced by the Homo sapiens-Elephas association in Punung (Java) around the latest part of the Middle Pleistocene (128-118 ka) (de Vos,1995). Westaway et al. (2007), Tougard (2001) and Suraprasit et al. (2016) proposed a Sino-Malayan migration pathway for the rainforest-inhabiting taxa via Northeastern Thailand during the late Middle Pleistocene. The Khok Sung mammalian fauna yielded at least four tropical forest-dwelling taxa (Capricornis sumatraensis, Bub-
Stegodon cf. orientalis

Elephas sp.

Bos sauveli

alus arnee

alus arnee, Sus barbatus and Elephas sp.) that presumably dispersed from mainland Southeast Asia to Java (Suraprasit et al., 2016). During all Plio-Pleistocene and until Holocene, the Sunda shelf was emerged and constituted a huge terrestrial peninsula, connected to Indochina. When covered by tropical forests, dispersal of forest species occurred and alternatively, during glacial periods, a savannah corridor developed, allowing dispersal of open grassland species (Suraprasit et al., 2019). However, the exact nature and chronology of these events are still incompletely known. 
TABLE 1 (continued).

\begin{tabular}{|c|c|c|}
\hline $\begin{array}{l}\text { Class/ } \\
\text { Order }\end{array}$ & Family & Species \\
\hline \multicolumn{3}{|l|}{ Reptilia } \\
\hline \multicolumn{3}{|c|}{ Testudines } \\
\hline \multicolumn{3}{|c|}{ Geoemydidae } \\
\hline & & Batagur cf. trivittata \\
\hline & & Heosemys annandalii \\
\hline & & Heosemys cf. grandis \\
\hline & & Malayemys sp. \\
\hline \multicolumn{3}{|c|}{ Trionychidae } \\
\hline & & Chitra sp. \\
\hline & & cf. Amyda sp. \\
\hline \multicolumn{3}{|c|}{ Crocodilia } \\
\hline \multicolumn{3}{|c|}{ Gavialidae } \\
\hline & & Gavialis cf. bengawanicus \\
\hline \multicolumn{3}{|c|}{ Crocodylidae } \\
\hline & & Crocodylus cf. siamensis \\
\hline \multicolumn{3}{|c|}{ Squamata } \\
\hline \multicolumn{3}{|c|}{ Varanidae } \\
\hline & & Varanus sp. \\
\hline \multicolumn{3}{|c|}{ Boidae } \\
\hline & & Python sp. \\
\hline \multicolumn{3}{|c|}{ Actinopterygii } \\
\hline \multicolumn{3}{|c|}{ Siluridae indet. } \\
\hline \multicolumn{3}{|l|}{ Aves } \\
\hline Galliform & indet. & \\
\hline
\end{tabular}

\section{Chronology}

A combination of palaeomagnetism and biochronology consistently points towards a late Middle Pleistocene age for the fossiliferous layer. The vertebrate assemblage and its attribution to the Ailuropoda-Stegodon association (Suraprasit et al., 2016) suggested a broad biochronological age range covering the Middle to Late Pleistocene (Kahlke 1961). This inference was mostly based on the identification of the fossil form of the spotted hyaena Crocuta crocuta ultima, documented at Khok Sung by a complete skull (Suraprasit et al., 2015). In Asia, the first appearance of Crocuta crocuta was recorded from the Middle Pleistocene layers (> $400 \mathrm{ka}$ ) of Zhoukoudian locality 1, northeastern China (Pei, 1934; Shen et al., 2009; Sheng et al., 2014). However, recent studies also documented the survival of spotted hyaenas into the Late Pleistocene (e.g., Nam Lot in Laos: (Bacon et al., 2012, 2015) and Boh Dambang in
Cambodia (Bacon et al., 2018)). In addition, Martin et al. (2012) suggested an Early Pleistocene age for the Khok Sung faunal assemblage. However, this was based on a limited study of the fauna and should thus be regarded with caution.

During the excavation, large man-made outcrops allowed to draw the detailed stratigraphic section and to collect samples for magnetostratigraphic analysis, whose results were summarized in Suraprasit et al. (2015). The palaeomagnetic analysis of the Khok Sung section (Figure 2) showed a dominantly normal polarity along the sequence. Consequently, the deposits can reasonably be correlated with the Brunhes chron (Suraprasit et al., 2015), indicating thus a Middle to Late Pleistocene age (< $772 \mathrm{ka}$, Okada et al., 2017). Interestingly, a short interval of reverse polarity was detected in lenses of silty mud within unit $F$ (Suraprasit et al., 2015). In combination with biochronological evidence, this interval was first tentatively correlated to either the Iceland Basin or 
TABLE 2. Details of the five fossil teeth collected from unit F for ESR dating purpose.

\begin{tabular}{ccl}
\hline Lab code & Collection number & \multicolumn{1}{c}{ Description } \\
\hline 3545 & DMR-KS-05-03-00-107 & Molar fragment of Stegodon cf. orientalis \\
3546 & DMR-KS-05-03-28-13 & Left M3 of Bubalus arnee \\
3547 & DMR-KS-05-03-31-5 & Right M1 of Bubalus arnee \\
3548 & DMR-KS-05-04-01-7 & Right P3 fragment of Bos sauveli \\
3549 & DMR-KS-05-03-23-2 & Left M1 or M2 of Bos sauveli \\
\hline
\end{tabular}

Pringle Falls excursion, dated to $211 \mathrm{ka}$ or $188 \mathrm{ka}$, respectively (Singer, 2014). The stratigraphic positions of the fossiliferous layer and palaeomagnetic sampling points suggest that the faunal assemblage and the excursion are very close in age.

\section{MATERIAL AND METHODS}

\section{Sampling and Preparation}

Five fossil teeth of large mammals were selected in 2015 from the palaeontological collection for combined U-series/ ESR dating (Table 2 and Supplementary Material, Figure S1). They were initially collected during the emergency excavation carried out between 9 March and 10 April 2005 and originate from stratigraphic unit $\mathrm{F}$ (Figure 2). Although excavation was carried out during a dry period, the conditions were made complicated by the high groundwater level. The site had to be pumped out to access the fossiliferous level (Figure 3). Nowadays, the site is several meters under the water table, thus neither further sediment sampling nor gamma dose rate measurements could be carried out. The only way to evaluate the environmental dose rate was to collect sediment samples attached to different fossils from the palaeontological collection. Thirteen sediment

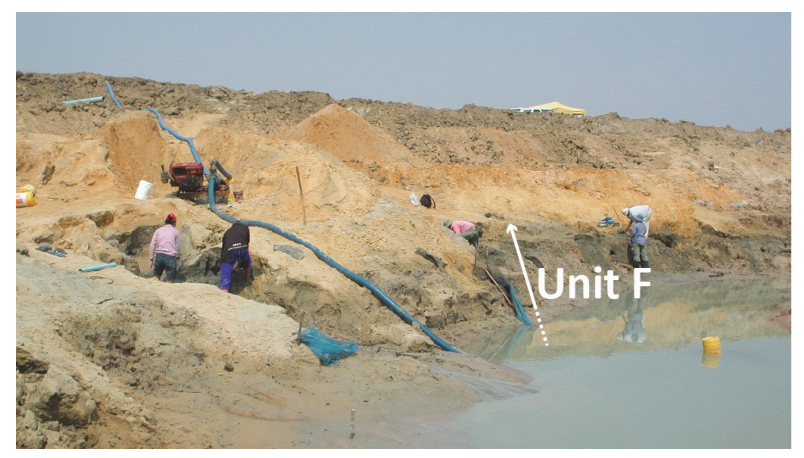

FIGURE 3. Khok Sung locality during excavation in 2005 (picture from Y. Chaimanee). The dark grey sediment corresponds to the fossiliferous layer (unit F). The lower part of unit $F$ is below the water and not visible on the picture. samples were taken to evaluate the variability of the environmental radioactivity within unit F. Additionally, laboratory observations showed the presence of a thin dark crust covering the fossils, which was therefore also sampled for further laboratory analyses.

\section{ESR Measurements}

The teeth were prepared following a standard ESR dating procedure based on enamel powder (e.g., Duval et al., 2011): the enamel layer was mechanically separated from the other dental tissues and both inner and outer surfaces were removed with a dentist drill to eliminate the volume that received an external alpha dose. One sample was collected from each tooth, except for 3546. For this tooth, two enamel samples were collected from different areas of the tooth in order to evaluate the possible impact of tooth geometry on the age results: one where the enamel is surrounded on both sides by dental tissues (sample B) and another one for which enamel has only one adjacent tissue (sample A). All enamel samples were ground and sieved $<200 \mu \mathrm{m}$. ESR dose evaluation was carried out using the Multiple Aliquot Additive Dose (MAAD) method. The powder was split into 12 aliquots and irradiated at CENIEH (Spain) with Gammacell 1000 Cs-137 gamma source (dose rate $=6.9 \mathrm{~Gy} / \mathrm{min}$ ) to the following dose steps: 0 , 5.0, 10.1, 20.1, 40.2, 80.4, 160.7, 321.4, 642.8, 1005, 2010 and 4019 Gy.

ESR measurements were carried out with a Bruker Elexsys 500 spectrometer at the Research School of Earth Sciences (RSES) of the Australian National University (Canberra, Australia), using the following acquisition parameters: 3-15 scans, 2 $\mathrm{mW}$ microwave power, 1024 points resolution, 12 $\mathrm{mT}$ sweep width, $50 \mathrm{kHz}$ modulation frequency, 0.1 $\mathrm{mT}$ modulation amplitude, $20 \mathrm{~ms}$ conversion time and $5 \mathrm{~ms}$ time constant. The ESR intensities were extracted from T1-B2 peak-to-peak amplitudes of the ESR signal (Grün, 2000a), and then normalized to the corresponding number of scans and aliquot mass. All aliquots of a given sample were 
measured within a short time interval $(<1 \mathrm{~h})$. This procedure was repeated three times over successive days without removing the enamel from the ESR tubes between measurements in order to evaluate measurement precision. The difference was $\leq 1 \%$ between the three repeated measurements, which resulted in an equivalent dose $\left(D_{E}\right)$ precision of $\leq 2 \%$ (Table 3 ).

\section{ESR Dose Evaluation}

The $D_{E}$ values were obtained by fitting a single saturating exponential (SSE) through the mean ESR intensities derived from the three repeated measurements with the Microcal OriginPro 9.1. software, which utilizes a Levenberg-Marquardt algorithm by chi-square minimization. Data were weighted by the inverse of the squared ESR intensity (1//2) (Grün and Brumby, 1994). ESR dose response curves (DRCs) are shown in Figure 4. To avoid $D_{E}$ overestimation, the dose response was restricted to $D_{\text {max }} / D_{E}$ ratios of between 5 and 10 (see Table 3) as recommended by Duval and Grün (2016). Consequently, maximum irradiation dose values $\left(D_{\text {max }}\right)$ of between 642 and 2009 Gy were used depending on the magnitude of the $\mathrm{D}_{\mathrm{E}}$. Resulting $D_{E}$ values vary between $-6 \%$ and $+2 \%$ compared with those derived from $D_{\max }=4019 \mathrm{~Gy}$ and are overall slightly lower by about $3 \%$ on average (see comparison provided in Supplementary Material Table S2). $D_{E}$ estimates show a 1-sigma overlap for $5 / 6$ samples, while all results are consistent at a 2-sigma confidence interval. The adjustment of $D_{\max }$ has therefore only a very limited impact on the $D_{E}$ estimates, although it induces an overall increase of the associated $D_{E}$ error by about $70 \%$ in average, as the result of a lower number of experimental available for the fitting even though the relative 1-sigma $D_{E}$ errors on the fitting remain very low (3.8\% on average).

\section{U-series Analysis of Dental Tissues}

Laser ablation (LA) U-series analyses were carried out at RSES, using a custom-built laser sampling system interfaced between an ArF Excimer laser and a MC-ICP-MS Finnigan Neptune (for details, see Eggins et al., 2003, 2005), following principles and procedures described in Grün et al. (2014). In each tooth, LA transects made of several ablation points were performed across enamel and dentine tissues (see Supplementary Material, Figure S1). For each dental tissue, the resulting analytical data derived from all individual laser ablation spots were merged to provide the pseudo-bulk data inputs for the ESR age calculations.

\section{Dose Rate Evaluation and Combined U-series/ ESR Age Calculation}

Age calculations were performed with a water content of $0 \%$ in the enamel. The US model assumes a gradual U-uptake over time following a one parameter diffusion equation. In comparison, the CSUS model is based on the assumption that all of the uranium migrated into the sample at a time given by the closed system U-series age. The CSUS-ESR age result is typically the maximum age that can be derived from a given U-series and ESR data set. Age calculations using the US-ESR and CSUS-ESR models encompass all possible uptake scenarios. If the dose rates derived from the internal uranium concentrations are low, the differences between the US-ESR and CSUS-ESR models are small. This is not the case when the

TABLE 3. ESR results derived from the dating analyses of the six tooth samples. Note that samples $3546 \mathrm{~A}$ and $3546 \mathrm{~B}$ belong to the same tooth. Measurement precision is expressed as the mean coefficient of variation of the ESR intensities derived from all the aliquots of a given sample after the three repeated measurements. $D_{E}$ precision is the variability of the $D_{E}$ values derived from the repeated measurements of a given sample. The final $D_{E}$ error is a combination of the fitting error (see Figure 4 ) and the error on the calibration of the irradiation source $(2.3 \%)$.

\begin{tabular}{cccccc}
\hline Sample & $\begin{array}{c}\text { Measurement } \\
\text { precision } \\
(\mathbf{\%})\end{array}$ & $\begin{array}{c}\mathbf{D}_{\mathrm{E}} \\
\text { precision } \\
\mathbf{( \% )}\end{array}$ & Adj. r-Square & $\begin{array}{c}\mathbf{D}_{\mathrm{E}} \text { value } \\
(\mathbf{G y})\end{array}$ & $\mathbf{D}_{\text {max }} / \mathbf{D}_{\mathrm{E}}$ \\
\hline 3545 & 1.0 & 0.8 & 0.9972 & $73.2 \pm 4.2$ & 8.8 \\
$3546 \mathrm{~A}$ & 0.8 & 2.0 & 0.9988 & $99.4 \pm 4.3$ & 6.5 \\
$3546 \mathrm{~B}$ & 0.9 & 0.5 & 0.9990 & $131.5 \pm 5.1$ & 7.6 \\
3547 & 0.9 & 0.7 & 0.9983 & $135.7 \pm 6.3$ & 7.4 \\
3548 & 0.5 & 0.3 & 0.9983 & $313.0 \pm 13.1$ & 6.4 \\
3549 & 0.9 & 0.6 & 0.9988 & $124.0 \pm 4.9$ & 8.1 \\
\hline
\end{tabular}



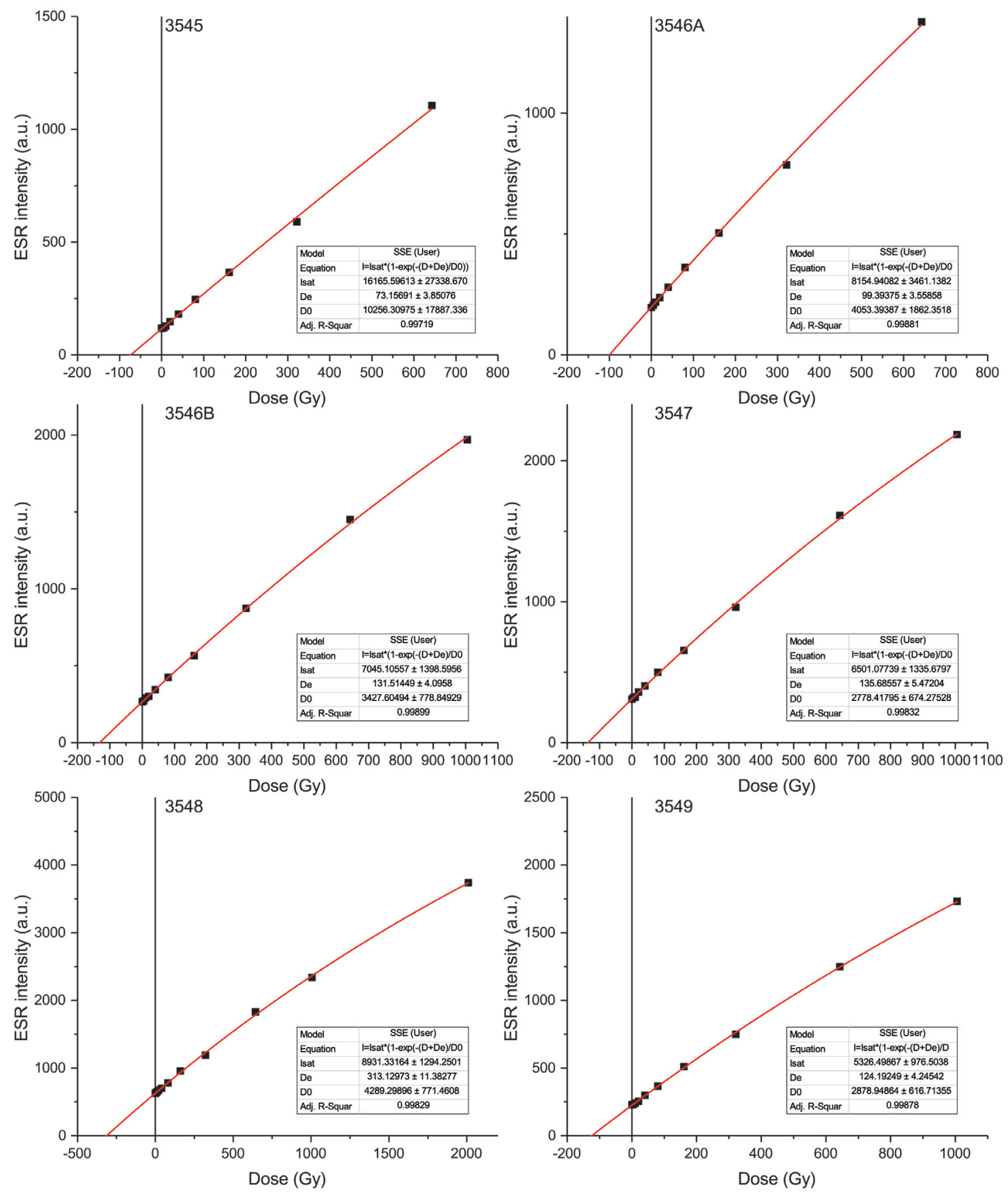

FIGURE 4. ESR dose response curves obtained for the six tooth enamel samples. The equivalent dose $\left(D_{E}\right)$ values were obtained by fitting a single saturating exponential (SSE) through the mean ESR intensities derived from the three repeated measurements.

dose rate of a tooth is dominated by the uranium in the various dental tissues.

The following parameters were used for the dose rate calculations: an alpha efficiency of $0.13 \pm$ 0.02 (Grün and Katzenberger-Apel, 1994), Monte-
Carlo beta attenuation factors from Marsh (1999) and dose rate conversion factors from Adamiec and Aitken (1998). $U$ and Th and K concentrations in raw sediment $(n=13$, labelled \#s1 to \#s13) and crust samples ( $n=4$, labelled \#c1 to \#c4) were 
TABLE 4. Radioelement concentrations obtained from the ICP-MS analyses of several samples taken from the raw sediment of unit F and from the crust attached to the fossil bones. Minimum, maximum and mean values and associated one standard error are displayed. The corresponding coefficients of variation are displayed in parenthesis.

\begin{tabular}{|c|c|c|c|c|}
\hline Sample ID & Associated fossil remain & U (ppm) & Th (ppm) & K (ppm) \\
\hline \multicolumn{5}{|c|}{ Sediment samples } \\
\hline$\#$ 1 1 & Turtle plate & $1.18 \pm 0.08$ & $2.79 \pm 0.13$ & $0.25 \pm 0.01$ \\
\hline \#s2 & Gavialis plate & $7.98 \pm 0.29$ & $1.99 \pm 0.10$ & $0.31 \pm 0.01$ \\
\hline \#s3 & Stegodon foot bone & $8.28 \pm 0.30$ & $2.74 \pm 0.12$ & $0.30 \pm 0.01$ \\
\hline \#s4 & Stegodon cf. orientalis vertebra & $2.49 \pm 0.11$ & $2.37 \pm 0.11$ & $0.40 \pm 0.02$ \\
\hline \#s5 & Stegodon cf. orientalis vertebra & $1.78 \pm 0.09$ & $2.45 \pm 0.11$ & $0.37 \pm 0.01$ \\
\hline \#s6 & Bubalus arnee horn core & $8.69 \pm 0.31$ & $5.66 \pm 0.24$ & $0.58 \pm 0.02$ \\
\hline \#s7 & Bubalus arnee vertebra & $0.96 \pm 0.08$ & $2.48 \pm 0.11$ & $0.26 \pm 0.01$ \\
\hline$\#$ \$8 & Large bovid long bone & $1.44 \pm 0.09$ & $3.71 \pm 0.16$ & $0.43 \pm 0.02$ \\
\hline$\#$ s9 & Rhinoceros unicornis calcaneus & $3.05 \pm 0.13$ & $1.75 \pm 0.09$ & $0.45 \pm 0.02$ \\
\hline \#s10 & Mandible of cervid & $2.47 \pm 0.11$ & $2.71 \pm 0.12$ & $0.27 \pm 0.01$ \\
\hline \#s11 & Skull of Bubalus arnee & $2.75 \pm 0.12$ & $3.06 \pm 0.14$ & $0.46 \pm 0.02$ \\
\hline \#s12 & Skull of Bubalus arnee & $2.87 \pm 0.12$ & $2.73 \pm 0.12$ & $0.36 \pm 0.01$ \\
\hline \multirow[t]{3}{*}{ \#s13 } & Large bovid vertebra & $12.48 \pm 0.44$ & $3.31 \pm 0.15$ & $0.41 \pm 0.02$ \\
\hline & Range & $0.96-8.69$ & $1.75-5.66$ & $0.25-0.58$ \\
\hline & Mean and standard error & $\begin{array}{c}4.34 \pm 1.02 \\
(23.6 \%)\end{array}$ & $\begin{array}{c}2.90 \pm 0.27 \\
(9.3 \%)\end{array}$ & $\begin{array}{l}0.37 \pm 0.03 \\
(7.1 \%)\end{array}$ \\
\hline Sample ID & $\begin{array}{l}\text { Associated fossil remain } \\
\text { (sediment sample) }\end{array}$ & U (ppm) & Th (ppm) & K (ppm) \\
\hline \multicolumn{5}{|c|}{ Crust samples } \\
\hline \#c1 & Stegodon cf. orientalis vertebra (\#s4) & $0.58 \pm 0.07$ & $2.09 \pm 0.10$ & $0.34 \pm 0.01$ \\
\hline$\# \mathrm{c} 2$ & Stegodon cf. orientalis vertebra (\#s4) & $0.55 \pm 0.07$ & $2.21 \pm 0.10$ & $0.33 \pm 0.01$ \\
\hline$\# \mathrm{c} 3$ & Stegodon cf. orientalis vertebra (\#s5) & $1.92 \pm 0.10$ & $7.79 \pm 0.33$ & $0.63 \pm 0.02$ \\
\hline \multirow[t]{3}{*}{ \#c4 } & Large bovid long bone (\#s8) & $0.78 \pm 0.07$ & $1.68 \pm 0.09$ & $0.37 \pm 0.01$ \\
\hline & Range & $0.55-1.92$ & $1.68-7.79$ & $0.33-0.63$ \\
\hline & Mean and standard error & $\begin{array}{c}1.02 \pm 0.32 \\
(32.0 \%)\end{array}$ & $\begin{array}{l}4.03 \pm 1.45 \\
(36.1 \%)\end{array}$ & $\begin{array}{l}0.43 \pm 0.07 \\
\quad(16.4 \%)\end{array}$ \\
\hline
\end{tabular}

determined by Genalysis Laboratory Services using Inductively Coupled Plasma Mass Spectrometry analyses after a four-acid digest preparation procedure (Table 4). The elemental concentration values were used to derive the beta and gamma dose rates. Post-Rn equilibrium was assumed in dental tissues and sediment. The external beta dose rate utilised a sediment/enamel/dentine geometry for all samples, except for 3546B, which had the enamel layer surrounded on both sides by dental tissues. For this sample a cement /enamel/ dentine configuration was used instead (see Duval, 2015). The thickness of the overburden was assumed to be $5 \pm 1 \mathrm{~m}$. Cosmic dose rates were calculated from Prescott and Hutton (1988, 1994). Because unit $F$ is currently below the ground water table, a high water content of $30 \pm 10 \%$ was used for the sediment dose rate calculations (see Figure
3). Similarly, a relatively high water content of $20 \pm$ $10 \%$ was also assumed for dentine and cement. Age calculations were performed with a water content of $0 \%$. Data inputs are displayed in Table 5. All errors are reported at a 1-sigma confidence level.

\section{RESULTS}

U-series dating results show apparent closedsystem ages ranging from 45 to $72 \mathrm{ka}$ for the enamel tissues of the five teeth, while the dentine overall displays somewhat younger ages between 14 and $77 \mathrm{ka}$ (Table 5). These results should be regarded as minimum age estimates for the fossil teeth, as uranium uptake in dental tissue may be delayed after the death of the organism (Grün et al., 2014). The U-series analyses do not show evidence of uranium leaching in any of the dental tissues, and uranium concentration in the enamel 
TABLE 5. Data inputs for the combined US-ESR age calculations. Note that samples $3546 \mathrm{~A}$ and $3546 \mathrm{~B}$ belong to the same tooth. Apparent U-series ages with 2- $\sigma$ errors are also provided in italics. Key: n/a = not applicable; (1) after Grün and Katzenberger-Apel (1994); (2) A 10\% error was assumed; (3) assumed value (note the impact of this parameter is minimum: by considering removed thicknesses of between 20 and $60 \mu \mathrm{m}$, the resulting age varies by <1\%); (4) used for beta dose rate evaluation only: these values correspond to $75 \%$ of the mean concentrations obtained from the crust samples and $25 \%$ of the mean concentrations derived from the sediment samples. All errors are given at a $1-\sigma$ confidence level.

\begin{tabular}{|c|c|c|c|c|c|c|}
\hline SAMPLE & 3545 & $3546 \mathrm{~A}$ & 3546B & 3547 & 3548 & 3549 \\
\hline \multicolumn{7}{|l|}{ Enamel } \\
\hline Dose (Gy) & $73.2 \pm 4.2$ & $99.4 \pm 4.3$ & $131.5 \pm 5.1$ & $135.7 \pm 6.3$ & $313 \pm 13.1$ & $124.0 \pm 4.9$ \\
\hline U (ppm) & $0.414 \pm 0.084$ & $0.109 \pm 0.035$ & $0.109 \pm 0.035$ & $0.158 \pm 0.049$ & $0.508 \pm 0.074$ & $0.391 \pm 0.580$ \\
\hline $234 U / 238 U$ & $1.802 \pm 0.008$ & $1.799 \pm 0.011$ & $1.799 \pm 0.011$ & $1.722 \pm 0.012$ & $1.581 \pm 0.010$ & $1.837 \pm 0.014$ \\
\hline${ }^{230} \mathrm{Th} / 234 \mathrm{U}$ & $0.480 \pm 0.004$ & $0.352 \pm 0.006$ & $0.352 \pm 0.006$ & $0.399 \pm 0.050$ & $0.500 \pm 0.014$ & $0.356 \pm 0.009$ \\
\hline Apparent $U$-series age (ka) & $67.5 \pm 1.6$ & $45 \pm 7$ & $45 \pm 7$ & $53.5 \pm 1.7$ & $72.0 \pm 5.4$ & $46.3 \pm 0.9$ \\
\hline Alpha Efficiency (1) & $0.13 \pm 0.02$ & $0.13 \pm 0.02$ & $0.13 \pm 0.02$ & $0.13 \pm 0.02$ & $0.13 \pm 0.02$ & $0.13 \pm 0.02$ \\
\hline Water content $(\%)$ & 0 & 0 & 0 & 0 & 0 & 0 \\
\hline $\begin{array}{l}\text { Initial enamel thickness } \\
(\mu \mathrm{m})(2)\end{array}$ & $4600 \pm 800$ & $1360 \pm 160$ & $1360 \pm 160$ & $960 \pm 270$ & $1100 \pm 220$ & $960 \pm 70$ \\
\hline \multicolumn{7}{|l|}{ Tissue 1 (dentine) } \\
\hline $\mathrm{U}(\mathrm{ppm})$ & $66.6 \pm 5.9$ & $1.88 \pm 0.07$ & $1.88 \pm 0.07$ & $37.7 \pm 8.1$ & $169.2 \pm 8.7$ & $67.1 \pm 5.3$ \\
\hline $234 U / 238 U$ & $1.811 \pm 0.003$ & $1.735 \pm 0.006$ & $1.735 \pm 0.006$ & $1.691 \pm 0.001$ & $1.624 \pm 0.001$ & $1.852 \pm 0.001$ \\
\hline${ }^{230} \mathrm{Th} / 234 \mathrm{U}$ & $0.133 \pm 0.001$ & $0.128 \pm 0.002$ & $0.128 \pm 0.002$ & $0.122 \pm 0.001$ & $0.526 \pm 0.001$ & $0.12 \pm 0.001$ \\
\hline Apparent U-series age (ka) & $15.4 \pm 0.1$ & $14.7 \pm 0.6$ & $14.7 \pm 0.6$ & $14.1 \pm 0.1$ & $76.9 \pm 0.4$ & $13.8 \pm 0.1$ \\
\hline Water $(\%)$ & $20 \pm 10$ & $20 \pm 10$ & $20 \pm 10$ & $20 \pm 10$ & $20 \pm 10$ & $20 \pm 10$ \\
\hline $\begin{array}{l}\text { Removed enamel } \\
\text { thickness }(\mu \mathrm{m})(2,3)\end{array}$ & $100 \pm 30$ & $30 \pm 10$ & $30 \pm 10$ & $30 \pm 10$ & $30 \pm 10$ & $30 \pm 10$ \\
\hline \multicolumn{7}{|l|}{ Tissue 2} \\
\hline U (ppm) & $\mathrm{n} / \mathrm{a}$ & $\mathrm{n} / \mathrm{a}$ & $158.1 \pm 8.9$ & $\mathrm{n} / \mathrm{a}$ & $\mathrm{n} / \mathrm{a}$ & $\mathrm{n} / \mathrm{a}$ \\
\hline $234 U / 238 U$ & $\mathrm{n} / \mathrm{a}$ & $\mathrm{n} / \mathrm{a}$ & $1.774 \pm 0.001$ & $\mathrm{n} / \mathrm{a}$ & $\mathrm{n} / \mathrm{a}$ & $\mathrm{n} / \mathrm{a}$ \\
\hline${ }^{230} \mathrm{Th} / 234 \mathrm{U}$ & $\mathrm{n} / \mathrm{a}$ & $\mathrm{n} / \mathrm{a}$ & $0.237 \pm 0.001$ & $\mathrm{n} / \mathrm{a}$ & $\mathrm{n} / \mathrm{a}$ & $\mathrm{n} / \mathrm{a}$ \\
\hline Apparent U-series age (ka) & $\mathrm{n} / \mathrm{a}$ & $\mathrm{n} / \mathrm{a}$ & $28.9 \pm 0.1$ & $\mathrm{n} / \mathrm{a}$ & $\mathrm{n} / \mathrm{a}$ & $\mathrm{n} / \mathrm{a}$ \\
\hline Water (\%) & $\mathrm{n} / \mathrm{a}$ & $\mathrm{n} / \mathrm{a}$ & $20 \pm 10$ & $\mathrm{n} / \mathrm{a}$ & $\mathrm{n} / \mathrm{a}$ & $\mathrm{n} / \mathrm{a}$ \\
\hline $\begin{array}{l}\text { Removed enamel } \\
\text { thickness }(\mu \mathrm{m})(2,3)\end{array}$ & $\mathrm{n} / \mathrm{a}$ & $\mathrm{n} / \mathrm{a}$ & $30 \pm 10$ & $\mathrm{n} / \mathrm{a}$ & $\mathrm{n} / \mathrm{a}$ & $\mathrm{n} / \mathrm{a}$ \\
\hline \multicolumn{7}{|l|}{ Sediment } \\
\hline U (ppm) (4) & $2.64 \pm 0.17$ & $2.64 \pm 0.17$ & $2.64 \pm 0.17$ & $2.64 \pm 0.17$ & $2.64 \pm 0.17$ & $2.64 \pm 0.17$ \\
\hline Th (ppm) ${ }^{(4)}$ & $2.80 \pm 0.09$ & $2.80 \pm 0.09$ & $2.80 \pm 0.09$ & $2.80 \pm 0.09$ & $2.80 \pm 0.09$ & $2.80 \pm 0.09$ \\
\hline $\mathrm{K}(\%)(4)$ & $0.34 \pm 0.07$ & $0.34 \pm 0.07$ & $0.34 \pm 0.07$ & $0.34 \pm 0.07$ & $0.34 \pm 0.07$ & $0.34 \pm 0.07$ \\
\hline Water (\%) & $30 \pm 10$ & $30 \pm 10$ & $30 \pm 10$ & $30 \pm 10$ & $30 \pm 10$ & $30 \pm 10$ \\
\hline $\begin{array}{l}\text { Removed thickness }(\mu \mathrm{m}) \\
(2,3)\end{array}$ & $30 \pm 10$ & $30 \pm 10$ & - & $30 \pm 10$ & $30 \pm 10$ & $30 \pm 10$ \\
\hline Depth (m) & $5 \pm 1$ & $5 \pm 1$ & $5 \pm 1$ & $5 \pm 1$ & $5 \pm 1$ & $5 \pm 1$ \\
\hline
\end{tabular}

samples is low ( $\leq 0.5 \mathrm{ppm})$, indicating the suitability of the tooth samples for the combined US-ESR dating approach.

The reconstruction of the environmental dose rate turned out to be the most challenging aspect of the ESR dating work performed at Khok Sung locality. This can only be achieved by using the sediment and crust samples taken from the palaeontological collection as, for the reasons explained above, no sediment sampling or gamma dose rate 
measurement is possible on site. Beta dose rate evaluation was performed by using mean radioelement concentrations from the crust and sediment samples (Table 4). The maximum thickness measured for the adhering crust $(\sim 0.6 \mathrm{~mm})$ was also taken into account, because it indicates that the relative contributions of the sediment and crust to the beta dose rate of the outer side of the enamel are of 0.25 and 0.75 , respectively (Duval and Martin, in press). Initial combined US-ESR age calculations were performed considering a gamma dose rate derived from the mean radioelement concentration values of the 13 sediment samples (470 \pm $79 \mu \mathrm{Gy} / \mathrm{a})$.

The resulting combined US-ESR ages are considerably older than the U-series estimates and range from $\sim 98$ to $\sim 195$ ka (Supplementary Material Table S3). The two samples dated from tooth 3546 provide very close ages (within $5 \%$ ) despite their different geometries. Sample $3545(98+16-$ 12 ) is more than $3 s$ outside the standard distribution of the other samples (168 $\pm 19 \mathrm{ka} ; \mathrm{n}=5)$ and may thus be considered as an outlier. Note that sample 3545 is a Stegodon molar fragment while all other samples were from bovids (Table 2). We do, however, not believe that the age difference is due to the species involved in the analyses. There has not been a report about Stegodon teeth being unsuitable for ESR dating. The young age of 3545 may be the result of a significantly lower dose rate environment, which is plausible given the variability in the 13 sediment samples (see discussion). Reworking from other layers is perhaps less likely as these did not contain any faunal elements, at least in the area that was excavated. In spite of large variations in the $D_{E}$ values $(\sim 58 \%$ for $n=6$; $\sim 54 \%$ when excluding sample 3545$)$ the scatter in the age estimates is significantly smaller $(\sim 11 \%$ when excluding sample 3545), which indicates that these samples form a single age population. We suspect the age scattering is most likely originating from the variability of the environmental dose rate. This question will be further discussed in section 4.1 , below.

Interestingly, US-ESR and CSUS-ESR age results are within error for 5 of 6 samples, the only exception here is sample 3548. This indicates that any uncertainties deriving from the uranium uptake model has a limited impact on the calculated age results for the majority of the sample. Sample 3548 , however, behaves differently. This tooth has apparently experienced an older uptake, with apparent $U$-series ages in both dentine and enamel of $>70 \mathrm{ka}$, which are the oldest of the data

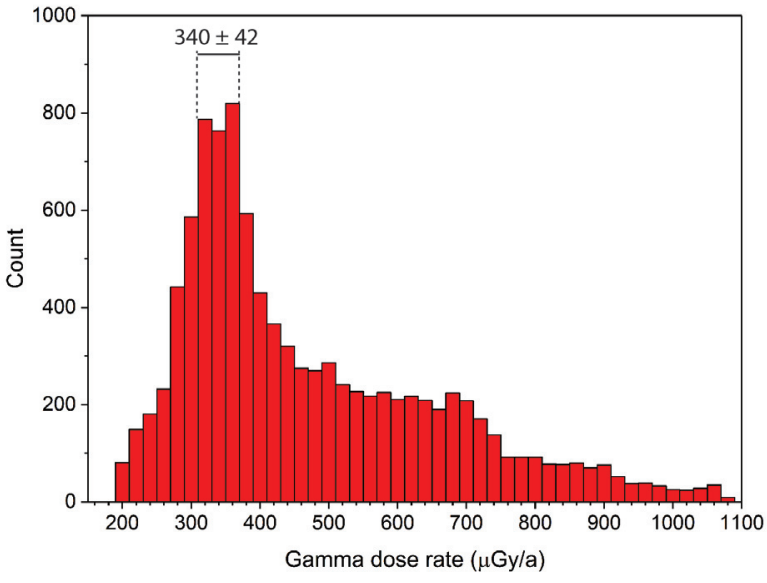

FIGURE 5. Gamma dose rate distribution derived from the 10,000 random simulations (bin size $=20 \mu \mathrm{Gy} / \mathrm{a}$ ). Values have been corrected for $30 \%$ water content. A local maximum may be observed at $340 \pm 42 \mu \mathrm{Gy} / \mathrm{a}$ (mean value and associated standard deviation derived from the three highest bars).

set. This difference, however, is not entirely reflected in the calculated ages: although 3548 yields the oldest age result of the data set, it is nevertheless within error with all but one sample (3545).

\section{DISCUSSION}

\section{Reliability of the ESR Age Results}

We have identified two main sources of uncertainty that may affect the reliability of our ESR dating results. The first one related to the evaluation of the gamma dose rate, which is complicated as it was impossible to perform in situ measurements. The second major source of uncertainty is linked to the water content considered for both dental tissues and sediment, given the unusual humidity conditions at the site and the fossils being close to the water table.

Gamma dose rate evaluation. In our initial age calculations (Supplementary Material Table S3), the gamma dose rate represents a significant proportion of the total dose rate, between $29 \%$ and $73 \%$ depending on the sample considered, while the beta dose rate from the sediment accounts for less than $8.5 \%$. Table 4 shows that sediment samples display a large range of concentration values: $\mathrm{U}(0.96$ to $8.69 \mathrm{ppm})$, Th (1.75 to $5.66 \mathrm{ppm})$ and $\mathrm{K}$ $(0.25$ to $0.58 \%)$. A closer look at the data shows that two groups of samples can be distinguished: 4 samples (\#s2, \#s3, \#s6 and \#s13) display significantly higher $\mathrm{U}$, Th and $\mathrm{K}$ concentrations than the 


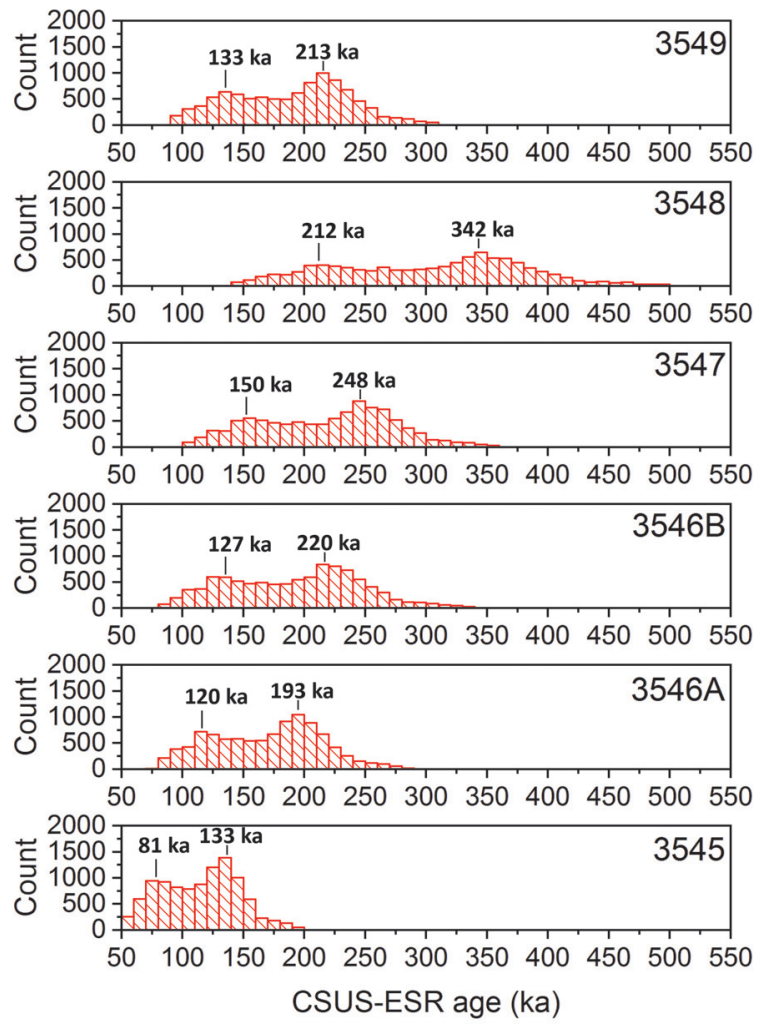

FIGURE 6. Stacked histograms of CSUS-ESR age distributions obtained for each sample.

average of the other 9 samples $(+340 \%,+28 \%$ and $+10 \%$, respectively). As we do not know how these different analytical results affect the age calculations, we performed gamma dose rate simulations using a random number generator to select sediment samples and their relative contributions to the gamma dose rate. A Quick Basic (a DOS-based program) script was specifically written for that purpose: sediment samples were randomly selected among the 13 available in Table 4 and successively added until the cumulative contributions reached $>95 \%$ (with the condition that each sample could only be selected once), the rest being then filled by another (last) randomly selected material. 10,000 calculations were performed, resulting in a highlyskewed dose distribution with a local maximum of around $340 \pm 42 \mu \mathrm{Gy} / \mathrm{a}$ (Figure 5). These results indicate that there is a higher probability that the gamma dose rate is around $340 \pm 42 \mu \mathrm{Gy} / \mathrm{a}$, i.e., significantly lower than the $470 \pm 79 \mu \mathrm{Gy} / \mathrm{a}$ initially considered for age calculations. The use of this simulated value would result in mean US-ESR ages of $194 \pm 39 \mathrm{ka}(n=6)$ and $208 \pm 18 \mathrm{ka}(n=5$, i.e., excluding the outlier 3545 ), which are older by about $24 \%$ than those initially derived.

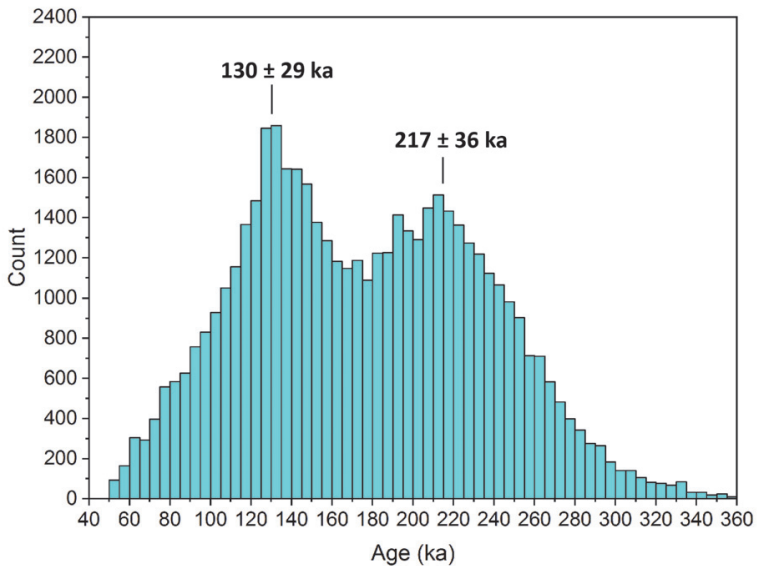

FIGURE 7. Age distribution considering all samples but 3548. Two Gaussian functions were fitted through each of the two peaks, resulting in mean values and associated 1 standard deviation of $130 \pm 29 \mathrm{ka}$ and $217 \pm 36$ ka.

With the exception of 3548 , the uranium uptake model has a limited impact on the calculated ages, as evidenced by the close agreement between US-ESR and CSUS-ESR ages. Because CSUS-ESR data involve the calculation of the dose resulting from the uranium in the dental tissues, it is possible to estimate the environmental dose component, generated by gamma, cosmic and, if applicable, beta sources. This environmental dose can then be used in conjunction with the gamma dose rate distribution to obtain a CSUS-ESR age distribution for each sample (Figure 6). All samples show a similar bimodal distribution, and two main populations around 120 to $150 \mathrm{ka}$ and 190 to 250 ka may be identified. All samples display at least one of these local maxima. Interestingly, the age distribution for 3545 suggest that this sample can no longer be considered as an outlier. The younger age result initially observed was most likely due to a locally lower gamma dose rate in the surrounding of the tooth. Because the CSUS-ESR and the USESR age estimates are within error for 5 of the 6 samples, it is possible to build a US-ESR histogram by summing the age distributions individually obtained for all samples but 3548 (Figure 7). The resulting bimodal distribution indicates that the two most probable age results for the fossil assemblage of Khok Sung are $130 \pm 29$ ka and $217 \pm 36$ ka, suggesting a correlation of the fossiliferous layer with either MIS5 or 7 (Lisiecki and Raymo, 2005).

From these results, it is therefore possible to extract the most probable gamma dose rate values for these two data sets, which are on average 658 
TABLE 6. Data outputs from the combined US-ESR age calculations. Note that samples $3546 \mathrm{~A}$ and $3546 \mathrm{~B}$ belong to the same tooth. Scenario A corresponds to the use of a gamma dose rate of $658 \pm 160 \mu \mathrm{Gy} / \mathrm{a}$, while scenario $B$ is based on $342 \pm 63 \mu \mathrm{Gy} / \mathrm{a}$ instead. Key: p-enamel, p-tissue1 (dentine) and p-tissue2 correspond to the uptake parameter values calculated for each dental tissue as in Grün et al. (1988). Post-Rn equilibrium was assumed in dental tissues and sediment. All errors are given at a $1 \sigma$ confidence level.

\begin{tabular}{|c|c|c|c|c|c|c|}
\hline SAMPLE & 3545 & $3546 A$ & 3546B & 3547 & 3548 & 3549 \\
\hline \multicolumn{7}{|l|}{ Scenario A } \\
\hline Internal dose rate $(\mu G y / a)$ & - & $14 \pm 6$ & $14 \pm 6$ & $21 \pm 9$ & $90 \pm 53$ & $54 \pm 16$ \\
\hline $\begin{array}{l}\text { Beta dose rate, tissue } 1 \text { (dentine) ( } \mu \mathrm{Gy} / \\
\text { a) }\end{array}$ & - & $4 \pm 0$ & $3 \pm 0$ & $118 \pm 40$ & $999 \pm 393$ & $175 \pm 41$ \\
\hline $\begin{array}{l}\text { Beta dose rate, sediment or tissue } 2 \\
(\mu \mathrm{Gy} / \mathrm{a})\end{array}$ & $13 \pm 3$ & $44 \pm 9$ & $295 \pm 91$ & $61 \pm 17$ & $54 \pm 13$ & $61 \pm 12$ \\
\hline Gamma dose rate $(\mu \mathrm{G} y / a)$ & $658 \pm 160$ & $658 \pm 160$ & $658 \pm 160$ & $658 \pm 160$ & $658 \pm 160$ & $658 \pm 160$ \\
\hline Cosmic dose rate $(\mu \mathrm{Gy} / \mathrm{a})$ & $109 \pm 12$ & $109 \pm 12$ & $109 \pm 12$ & $109 \pm 12$ & $109 \pm 12$ & $109 \pm 12$ \\
\hline Total dose rate $(\mu \mathrm{G} y / a)$ & - & $830 \pm 160$ & $1069 \pm 184$ & $968 \pm 166$ & $1911 \pm 427$ & $1058 \pm 166$ \\
\hline p-enamel & - & 0.35 & 0.41 & 0.31 & -0.03 & 0.27 \\
\hline p-tissue 1 (dentine) & - & 0.98 & 1.99 & 0.00 & -0.16 & 1.61 \\
\hline p-tissue 2 & - & - & 1.87 & - & - & - \\
\hline Combined US-ESR age (ka) & $\begin{array}{c}\text { age } \\
\text { calculation } \\
\text { impossible }\end{array}$ & $119+36-20$ & $123+30-21$ & $140+35-21$ & $163+47-29$ & $117+25-16$ \\
\hline Combined CSUS-ESR age (ka) & $79 \pm 16$ & $120 \pm 24$ & $133 \pm 28$ & $156 \pm 31$ & $216 \pm 45$ & $135 \pm 26$ \\
\hline \multicolumn{7}{|l|}{ Scenario B } \\
\hline Internal dose rate $(\mu \mathrm{Gy} / \mathrm{a})$ & $96 \pm 31$ & $10 \pm 4$ & $9 \pm 4$ & $15 \pm 6$ & $71 \pm 43$ & $37 \pm 10$ \\
\hline Beta dose rate, dentine ( $\mu \mathrm{G} y / a)$ & $40 \pm 11$ & $3 \pm 0$ & $1 \pm 0$ & $79 \pm 27$ & $794 \pm 332$ & $121 \pm 24$ \\
\hline $\begin{array}{l}\text { Beta dose rate, sediment or cement } \\
(\mu \mathrm{G} / \mathrm{a})\end{array}$ & $13 \pm 3$ & $44 \pm 9$ & $179 \pm 53$ & $61 \pm 17$ & $54 \pm 13$ & $61 \pm 12$ \\
\hline Gamma dose rate $(\mu \mathrm{Gy} / \mathrm{a}$ & $342 \pm 63$ & $342 \pm 63$ & $342 \pm 63$ & $342 \pm 63$ & $342 \pm 63$ & $342 \pm 63$ \\
\hline Cosmic dose rate $(\mu \mathrm{Gy} / \mathrm{a})$ & $109 \pm 12$ & $109 \pm 12$ & $109 \pm 12$ & $109 \pm 12$ & $109 \pm 12$ & $109 \pm 12$ \\
\hline Total dose rate $(\mu \mathrm{G} / \mathrm{a})$ & $601 \pm 72$ & $509 \pm 64$ & $638 \pm 83$ & $607 \pm 71$ & $1371 \pm 341$ & $671 \pm 70$ \\
\hline p-enamel & -0.37 & 1.66 & 1.84 & 1.50 & 0.59 & 1.43 \\
\hline p-tissue 1 (dentine) & 0.00 & 2.67 & 4.77 & 2.91 & 0.41 & 3.43 \\
\hline p-tissue 2 & - & - & 4.34 & - & - & - \\
\hline Combined US-ESR age (ka) & $121+21-15$ & $195+34-23$ & $206+34-28$ & $223+33-24$ & $228+65-40$ & $184+24-18$ \\
\hline Combined CSUS-ESR age (ka) & $134 \pm 15$ & $197 \pm 27$ & $227 \pm 34$ & $252 \pm 34$ & $351 \pm 52$ & $219 \pm 29$ \\
\hline
\end{tabular}

$\pm 160 \mu \mathrm{Gy} / \mathrm{a}$ and $342 \pm 63 \mu \mathrm{Gy} / \mathrm{a}$. These values were used to recalculate individual US-ESR and CSUS-ESR age estimates (see Table 6, with scenarios $A$ and $B$ corresponding to gamma dose rates of 658 and $342 \mu \mathrm{Gy} / \mathrm{a}$, respectively).

Water content. Our age calculations were performed considering relatively high long-term water content in both sediment $(30 \pm 10 \%)$ and dentine (20 $\pm 10 \%)$, while enamel was assumed to remain much less impacted by water fluctuations given its significantly higher mineral content and crystallinity (Elliott, 2002). Large errors were intentionally used to cover a range from 10 to $50 \%$ and 0 to $40 \%$ at the $2 \sigma$ confidence level, respectively, which most likely encompasses any water content fluctuation over time.

Nevertheless, in order to evaluate the sensitivity of the age results to the water content, several simulations were carried out using 15, 10 and $5 \%$ water content in dentine. They resulted in a relative age decrease of 2,4 and $6 \%$, respectively (Supplementary Material Figure S2). In comparison, water content in sediment of $20 \%$ or $10 \%$ would make the ages younger by $11 \%$ and $19 \%$, respectively (Supplementary Material Figure S2). These results illustrate the large contribution of the sediment to the total dose rate, compared to the dental tissues. 


\section{Comparison with Other Independent Chronological Evidence}

The ESR dating study indicates two possible ages for the Khok Sung assemblage, i.e., either $130 \pm 29$ ka (scenario A) or $217 \pm 36$ ka (scenario $B$ ). Firstly, none of these ages are in agreement with the Early Pleistocene biochronological assignation of Martin et al. (2012). From a methodological point view, we do not have any reason to prefer one or the other option. Consequently, the question lies now in whether independent biochronological, palaeomagnetic and palaeoclimate-inferred evidence can help to refine the chronological interpretation of the ESR dating results.

The Khok Sung mammalian fauna belongs to the Ailuropoda-Stegodon faunal complex, which is typically found in the palaeontological records of mainland Southeast Asia, and whose age ranges from the Early to Late Pleistocene (see Suraprasit et al., 2016 and references therein). In terms of composition, it shares many similarities with various other Thai cave localities despite of being one of the very few open-air sites in the region.

In particular, Suraprasit et al. (2016) reported six shared taxa with the assemblage from Tham Prakai Phet cave, Chaiyaphum Province (see Filoux et al., 2015 and references therein), including Crocuta crocuta ultima, which is usually considered as a good biochronological marker. Preliminary results from an ongoing combined USESR dating study of several fossil teeth from Tham Prakai Phet suggest a MIS4 age estimate for this assemblage (Filoux et al., 2018; Filoux and Wattanapituksakul, in press).

Khok Sung also shares nine species with Ban Fa Suai site (Cave of the Monk), Northern Thailand (Zeitoun et al., 2010), although most of the mammalian taxa from the latter are assigned to cf. In particular, a single fragmentary tooth attributed to an undetermined Hyaenidae was identified in the faunal assemblage, which may not be sufficient to undoubtedly confirm the presence of Crocuta at this site (Suraprasit et al., 2015). ESR dating of 3 large mammal teeth from different layers of the sedimentary infilling yielded Early uptake (EU) ESR age results ranging from $41.0 \pm 4.8 \mathrm{ka}$ at the base of the sequence to $15.5 \pm 1.4 \mathrm{ka}$ at the top (Zeitoun et al., 2010). While these age results should generally be regarded as minimum estimates for the fossils, the U-concentrations were low, and the alternative Linear uptake (LU) model yielded ESR age estimates less than 1.2 ka older, indicating the limited influence of the dental tissues on the dose rate evaluation. More recently, Zeitoun et al. (in press) reported the discovery of another similar palaeontological assemblage found at Ban Fa Suai II, another small cave opening located only a few hundreds of meters from the Cave of the Monk. Direct dating of three fossil teeth from that assemblage provided consistent minimum EUESR age estimates ranging between 45 and $50 \mathrm{ka}$. LU-ESR ages ranged between 50-55 ka. LU-ESR and EU-ESR age estimates were within error, indicating again the limited influence of uranium uptake models on the calculated ages. In summary, the ESR dating results indicate that both assemblages date to the second half of the Late Pleistocene. The presence of hyena at Ban $\mathrm{Fa}$ Suai II site, and also possibly at Ban Fa Suai, indicates the persistence of this carnivore until the latest part of the Late Pleistocene (MIS 2), limiting thus its biochrononological significance in the Southeast Asian palaeontological record (Filoux et al., 2015).

The large mammal fauna assemblage from Khok Sung is most similar in composition (10 shared taxa; Suraprasit et al., 2016) to that from Thum Wiman Nakin (Snake Cave), a cave in Northeastern Thailand where Crocuta crocuta ultima has also been identified (Tougard, 1998). At this site, the biochronological evidence suggests a slightly younger age for due to the occurrence of some modern taxa (e.g., Ailuropoda melanoleuca and Muntiacus muntjak) and the lack of an archaic Stegodon. This tentative age assignment should however be treated with some caution, because the taxonomic identification of the Thum Wiman Nakin fauna requires revisions, and the absence of some taxa may also be the result of the palaeoenvironmental differences between the two sites. Successive U-series dating analyses of calcitic formations overlying the fossiliferous layers at Thum Wiman Nakin provided minimum ages of $137+7 /-6$ $\mathrm{ka}$ and $169 \pm 11 \mathrm{ka}$ for the faunal assemblage (Esposito et al., 1998 and 2002). Additional Useries analyses of dental tissues from 20 teeth showed open system behaviours, with apparent ages ranging from $\sim 10 \mathrm{ka}$ to $>350 \mathrm{ka}$, and several samples showed uranium leaching (Esposito et al., 2002). Consequently, it is possible that the apparent old ages were caused by uranium leaching processes. This is, however, impossible to evaluate without combining U-series with ESR data (Grün et al., 1988), precluding thus the calculation of finite ages for these fossils. As of now, only the U-series ages on the calcitic deposits overlying the fossiliferous level provide a safe minimum age constraint of $169 \pm 11 \mathrm{ka}$ for the fossiliferous level. 


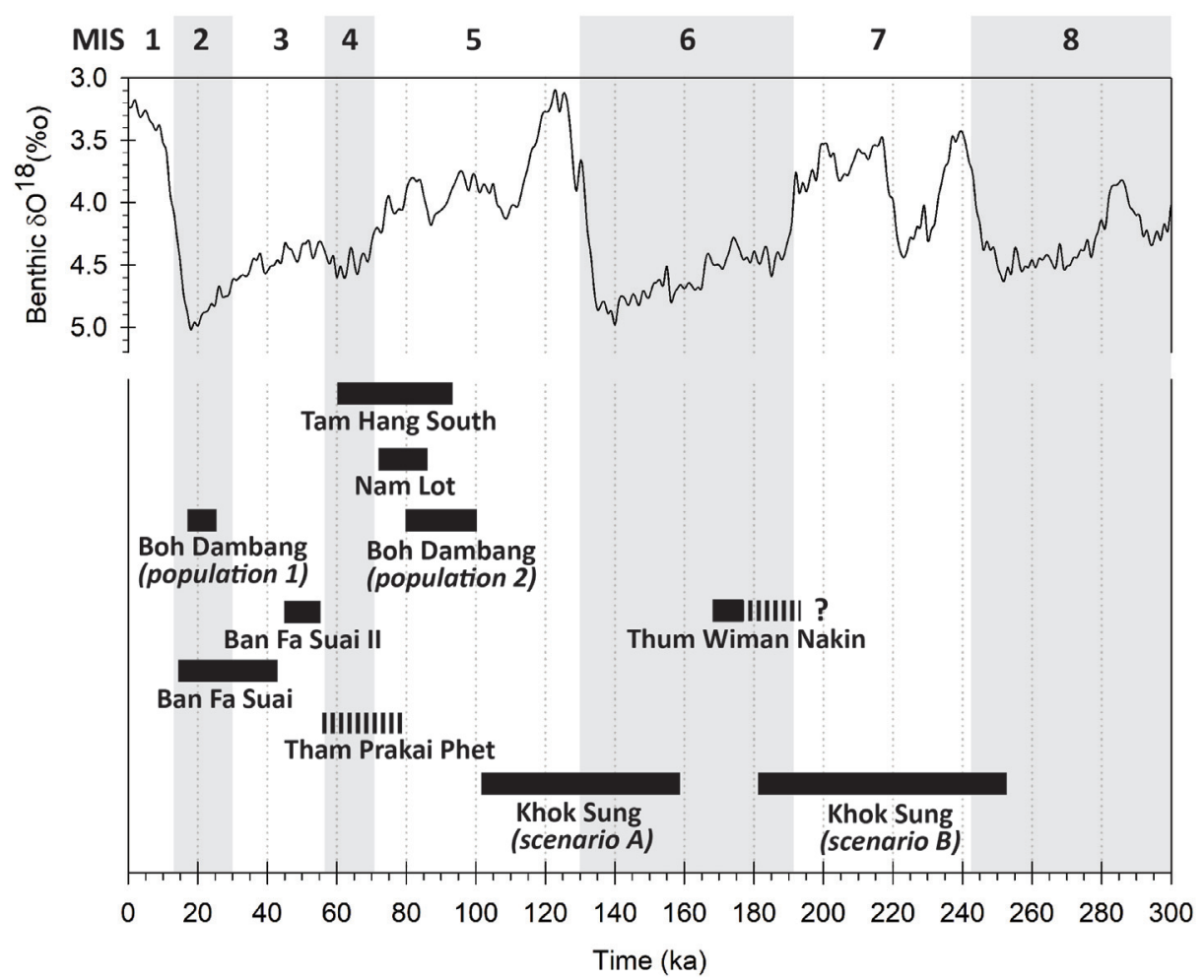

FIGURE 8. Age range of the sites mentioned in the text. Notes: (i) Thum Wiman Nakin site: minimum age constraint for the fossil assemblage; (ii) Tham Prakai Phet site: unpublished preliminary results from an ongoing investigation. MIS data from Lisiecki and Raymo (2005).

Outside of Thailand, the Khok Sung assemblage is close in composition (Suraprasit et al., 2016) with those from Boh Dambang, Cambodia, as well as Nam Lot and Tam Hang South, Laos (Bacon et al., 2018). However, a recent study at Boh Dambang showed that the faunal assemblage is likely to be a mixture of two populations of fossils with different ages (Bacon et al., 2018). A combination of luminescence, $U$-series and ESR methods applied to the sediment and fossil teeth correlates some of the fossils to the MIS2 (25-18 ka), while another population of fossil specimens of $\sim 100-80$ ka has also been identified as being most likely reworked from older deposits. Consequently, the biochronological significance of the assemblage should be treated with extreme caution. In comparison, luminescence dating of quartz and U-series dating of the flowstones at the two sites from Laos have provided an age range of 94-60 ka and 8672 ka for Tam Hang South and Nam Lot, respectively (Bacon et al., 2015).

Additional independent age constraints may potentially be obtained from the palaeomagnetic study. A few short magnetic excursion reversals have been documented in the Geomagnetic Instability Time Scale (GITS) for the time range covered by both ESR dating scenarios and may be tentatively correlated to the excursion observed within unit F. In particular, Singer (2014) identified two excursions between 220 and 180 ka, Pringle Falls and Iceland Basin excursions, dated to $212 \mathrm{ka}$ and $188 \mathrm{ka}$, respectively. The former excursion has been recorded on both terrestrial (volcanic) and marine deposits (Singer et al., 2008), while the other has only been recorded in marine sediments (Singer, 2014). In other words, none of them has ever been identified in non-volcanic continental sediment, so the probability to find one of these excursions in the fluvial deposits of Khok Sung locality is very limited. In comparison, the ESR age of $130 \pm 29$ ka would match the Blake event dated to $120 \pm 12$ ka (Singer, 2014), for which multiple continental records in different sedimentary environments have been documented (e.g., Sier et al., 2015).

Palaeoclimatic and palaeoenvironmental inferences derived from isotopic analyses of several mammal teeth may also provide an indirect but 
useful time constraint. Stable carbon isotopes indicate a $\mathrm{C}_{4}$ dominant grassland ecosystem with a mixture of some $\mathrm{C}_{3}$ plants environment at Khok Sung (Suraprasit et al., 2018). The authors also deduced a seasonal and humid climate for the lowland floodplain area based on stable oxygen isotopes and the cenogram method. This would be consistent with an interglacial climate, i.e., either MIS7 or MIS5, which are compatible with Scenario $B$ and $A$, respectively.

\section{Summary}

None of the independent evidence derived from the biochronology, palaeomagnetism and stable isotopic study could be used to favour one over the other ESR scenario.

The large majority of the sites showing similarities with the Khok Sung assemblage date to the Late Pleistocene (see overview in Figure 8) and are not older than MIS5. The ESR age of $130 \pm 29$ ka (scenario $A$ ) is consistent within error with these chronologies. The only exception is Thum Wiman Nakin site (minimum age of $\sim 169 \mathrm{ka}$ ), which, according to Suraprasit et al. (2016), presents the closest affinities with Khok Sung assemblage. This initially led the authors to suggest a slightly older age for the latter, which is also highly compatible with the ESR age of $217 \pm 36$ ka (scenario B). However, biochronological inferences are limited by three main factors, (i) the limited number of sites numerically dated in mainland Southeast Asia, (ii) the uncertainty on some taxonomical assignments for many assemblages and (ii) the significant difference in palaeoenvironmental conditions between Khok Sung and the other sites of the region, which are almost all cave sites.

The probability of identifying the Blake event $(120 \pm 12 \mathrm{ka})$ in fluvial deposits is somewhat higher than for the Pringle Falls or Iceland Basin excursions, but both correlations appear to be equally speculative in absence of additional evidence.

Finally, stable oxygen isotopes and the cenogram method both suggest a correlation to an interglacial climate, yielding thus either a MIS7 or early MIS5 age for the Khok Sung assemblage. Following Suraprasit et al. (2018), one may tentatively correlate the warm and humid conditions to stages MIS7.3, MIS7.1 or MIS5.5, as exemplified from the stable oxygen isotope data of stalagmites from Sanbao cave (Central China) (Wang et al., 2008) and from the atmospheric $\delta^{18} \mathrm{O}$ record from Vostok ice core (Antarctica) (Petit et al., 1999). Such a fine correlation should, however, be treated with extreme caution given the magnitude of the existing ESR age uncertainty.

\section{CONCLUSIONS}

We report here the results of the first numerical dating study of the Khok Sung vertebrate assemblage from Nakhon Ratchasima Province (Northeastern Thailand). Combined US-ESR dating of five teeth provide two possible ages of $130 \pm$ 29 ka and $217 \pm 36$ ka for the fossils. Both options are equally plausible, as independent evidence derived from other methods cannot help to favour one over the other option. These results illustrate the intrinsic limitations of the ESR dating method when fossil teeth are not specifically collected for ESR dating during the excavation, involving the recovery of the sediments in the immediate surroundings of the teeth and in situ gamma spectrometry. The lack of these has created significant uncertainties in the reconstruction of the environmental dose rate, leading to these two possible ages for the Khok Sung fauna, either MIS7 or early MIS5. Either way, these chronological results make Khok Sung as one of the oldest fossil assemblages directly dated in the region. New discoveries and future investigations are necessary to obtain more accurate taxonomic identifications and additional radiometric dates of large mammal assemblages in mainland Southeast Asia. They will help not only to achieve a more detailed biochronological subdivision of the long-range faunal association (Kahlke, 1961), but also to reach a definitive conclusion on the age of the Khok Sung assemblage.

\section{ACKNOWLEDGEMENTS}

We would like to thank Somsak Panha for sharing his facilities during the ESR dating fieldwork at Khok Sung, Mana Rugbumrung (D.M.R. Bangkok) and Bernard Marandat for their great help during excavations. Our thanks are also extended to Thunchanok Kawinate for redrawing the stratigraphic column. The authors are grateful to Les Kinsley, ANU, and Verónica Guilarte, CENIEH, for their support with the LA-ICP-MS measurements and gamma irradiations, respectively. This study would not have been possible without the help of Santiago Gil de la Vega, CENIEH, who made sure that the sediment samples could be delivered in due time to CENIEH. Aspects of this study have been funded by the Australian Research Council Future Fellowship grant FT150100215 granted to M.D., an ANU-CSC 
Scholarship to F.F., and by the C.N.R.S. "Eclipse" Program and the Department of Mineral Resources (Bangkok). We finally thank the three anonymous reviewers for their constructive comments, which have contributed to improve the quality of this work.

\section{REFERENCES}

Adamiec, G. and Aitken, M.J. 1998. Dose-rate conversion factors: update. Ancient TL, 16(2):3750.

Bacon, A.-M., Demeter, F., Duringer, P., Patole-Edoumba, E., Sayavongkhamdy, T., Coupey, A.S., Shackelford, L., Westaway, K.E., Ponche, J.-L., Antoine, P.-O., and Sichanthongtip, P. 2012. Les sites de Tam Hang, Nam Lot et Tam Pà Ling au nord du Laos. Des gisements à vertébrés du Pléistocène aux origines des Hommes modernes. CNRS Editions, Paris.

Bacon, A.-M., Duringer, P., Westaway, K., Joannes-Boyau, R., Zhao, J., Bourgon, N., Dufour, E., Pheng, S., Tep, S., Ponche, J.-L., Barnes, L., Blin, A., Patole-Edoumba, E., and Demeter, F. 2018. Testing the savannah corridor hypothesis during MIS2: The Boh Dambang hyena site in southern Cambodia. Quaternary International, 464:417-439. https://doi.org/10.1016/ j.quaint.2017.10.047

Bacon, A.-M., Westaway, K.E., Antoine, P.-O., Duringer, P., Blin, A., Demeter, F., Ponche, J.-L., Zhao, J.-X., Barnes, L.M., Sayavonkhamdy, T., Thuy, N.T.K., Long, V.T., Patole-Edoumba, E., and Shackelford, L. 2015. Late Pleistocene mammalian assemblages of Southeast Asia: New dating, mortality profiles and evolution of the predator-prey relationships in an environmental context. Palaeogeography, Palaeoclimatology, Palaeoecology, 422:101-127. https://doi.org/10.1016/j.palaeo.2015.01.011

Bird, M. I., Taylor D., and Hunt C. 2005. Palaeoenvironments of insular Southeast Asia during the Last Glacial Period: a savanna corridor in Sundaland? Quaternary Science Reviews, 24(20):2228-2242. https://doi.org/10.1016/j.quascirev.2005.04.004

Chaimanee, Y., Yamee, C., Tian, P., and Khaowiset, K. 2005. Fossils and their managements at Ban Khok Sung, Muang District, Nakhon Ratchasima Province, NE Thailand. Academic report no. DMR 25/2005. Department of Mineral Resources, Bangkok, Thailand. (In Thai)

Charusiri, P., Daorerk, V., Krowchan, V., Klongsara, N., Kosuwan, S., Srirattanachatchawan, V., and Santatiwongchat, U. 2002. Quaternary tektites and their sediment hosts at Ban Thachang sand pit, Chaloem Prakiat, Nakhon Ratchasima, NE Thailand: stratigraphy and its ages. In Mantajit, N. (ed.), Proceedings of the Symposium on Geology of Thailand. Department of Mineral Resources, Bangkok, p. 9.

Claude, J., Naksri, W., Boonchai, N., Buffetaut, E., Duangkrayom, J., Laojumpon, C., Jintasakul, P., Lauprasert, K., Martin, J., Suteethorn, V., and Tong, H. 2011. Neogene reptiles of northeastern Thailand and their paleogeographical significance. Annales de Paléontologie, 97:113-131. https://doi.org/10.1016/j.annpal.2011.08.002

Cook, C.D.K., 1996. Aquatic and Wetland Plants of India. Oxford University Press, New York.

de Vos, J. 1995. The migration of Homo erectus and Homo sapiens in Southeast Asia and the Indonesian archipelago, p. 239-260. In Bower, J.R.F. and Sartono, S. (eds.), Human Evolution on the Ecological Context. Vol. I, Centennial Foundation, Leiden University, Netherlands.

Duangkrayom, J., Ratanasthien, B., Jintasakul, P., and Carling, P.A. 2014. Sedimentary facies and paleoenvironment of a Pleistocene fossil site in Nakhon Ratchasima province, northeastern Thailand. Quaternary International, 325:220-238. https://doi.org/10.1016/ j.quaint.2013.07.048

Duval, M. 2015. Electron Spin Resonance Dating of fossil tooth enamel, p. 239-246. In Rink, W.J. and Thompson, J.W. (eds.), Encyclopedia of Scientific Dating Methods, Springer Netherlands. https://doi.org/10.1007/978-94-007-6304-3_71

Duval, M., Falguères, C., Bahain, J.-J., Grün, R., Shao, Q., Aubert, M., Hellstrom, J., Dolo, J.-M., Agusti, J., Martínez-Navarro, B., Palmqvist, P., and Toro-Moyano, I. 2011. The challenge of dating Early Pleistocene fossil teeth by the combined Uranium series-electron spin resonance method: the Venta Micena palaeontological site (Orce, Spain). Journal of Quaternary Science, 26(6):603-615. https://doi.org/10.1002/jqs.1476 
Duval, M. and Grün, R. 2016. Are published ESR dose assessments on fossil tooth enamel reliable? Quaternary Geochronology, 31:19-27. https://doi.org/10.1016/j.quageo.2015.09.007

Duval, M. and Martin, L. 2019. ESR dating of fossil teeth: in which extent the thickness of adjacent tissues should be taken into account in the external beta dose rate evaluation? Geochronometria, 46:102-110. https://doi.org/10.1515/geochr-2015-0105

Elliott, J. 2002. Calcium phosphate biominerals. Reviews in Mineralogy and Geochemistry, 48(1):427-453.

Eggins, S., Grün, R., Pike, A., Shelley, A., and Taylor, L. 2003. 238U, 232Th profiling and U-series isotope analysis of fossil teeth by laser ablation ICPMS. Quaternary Science Reviews, 22:1373-1382. https://doi.org/10.1016/S0277-3791(03)00064-7

Eggins, S.M., Grün, R., McCulloch, M.T., Pike, A.W.G., Chappell, J., Kinsley, L., Mortimer, G., Shelley, M., Murray-Wallace, C.V., Spötl, C., and Taylor, L. 2005. In situ U-series dating by laser-ablation multi-collector ICPMS: new prospects for Quaternary geochronology. Quaternary Science Reviews, 24:2523-2538. https://doi.org/10.1016/j.quascirev.2005.07.006

Esposito, M., Chaimanee, Y., Jaeger, J.-J., and Reyss, J.-L. 1998. Datation des concrétions carbonatées de la "Grotte du Serpent"' (Thaïlande) par la méthode Th/U. Comptes Rendus de l'Académie des Sciences, Série IIA, 326:603-608. https://doi.org/10.1016/S12518050(98)80250-4

Esposito, M., Reyss, J.-L., Chaimanee, Y., and Jaeger, J.-J. 2002. U-series dating of fossil teeth and carbonates from snake cave, Thailand. Journal of Archaeological Science, 29:341-349. https://doi.org/10.1006/jasc.2002.0718

Filoux, A. and Wattanapituksakul, A. In press. The Late Pleistocene Orangutan from Tham Prakai Phet: New discoveries. Annales de Paléontologie. https://doi.org/10.1016/ j.annpal.2019.03.004

Filoux, A., Wattanapituksakul, A., Lespes, C., Martin, J., Becam, G., Liard, R., Thongcharoenchaikit, C., Grün, R., and Duval M. 2018. Tham Prakai Phet (Thailand): a new biochronological benchmark for mainland Southeast Asia. 5th International Paleontological Congress - Paris, 9th-13th July 2018, p. 655.

Filoux, A., Wattanapituksakul, A., Lespes, C., and Thongcharoenchaikit, C. 2015. A Pleistocene mammal assemblage containing Ailuropoda and Pongo from Tham Prakai Phet cave, Chaiyaphum Province, Thailand. Geobios, 48:341-349. https://doi.org/10.1016/ j.geobios.2015.07.003

Grote, P. 2007. Studies of fruits and seeds from the Pleistocene of northeastern Thailand. Courier Forschunginstitut Senckenberg, 258:171-181.

Grün, R. 2000a. Methods of dose determination using ESR spectra of tooth enamel. Radiation Measurements, 32(5-6), 767-772. https://doi.org/10.1016/S1350-4487(99)00281-4

Grün, R. 2000b. An alternative model for open system U-series/ESR age calculations: (closed system U-series)-ESR, CSUS-ESR. Ancient TL, 18(1):1-4.

Grün, R. 2009. The DATA program for the calculation of ESR age estimates on tooth enamel. Quaternary Geochronology, 4(3):231-232. https://doi.org/10.1016/j.quageo.2008.12.005

Grün, R. and Brumby, S. 1994. The assessment of errors in past radiation doses extrapolated from ESR/TL dose-response data. Radiation Measurements, 23(2-3):307-315. https:// doi.org/10.1016/1350-4487(94)90057-4

Grün, R., Eggins, S., Kinsley, L., Mosely, H., and Sambridge, M. 2014. Laser ablation U-series analysis of fossil bones and teeth. Palaeogeography, Palaeoclimatology, Palaeoecology, 416, 150-167. https://doi.org/10.1016/j.palaeo.2014.07.023

Grün, R. and Katzenberger-Apel, O. 1994. An alpha irradiator for ESR dating. Ancient TL, 12(2):35-38.

Grün, R., Schwarcz, H.P., and Chadam, J. 1988. ESR dating of tooth enamel: Coupled correction for U-uptake and U-series disequilibrium. International Journal of Radiation Applications and Instrumentation. Part D. Nuclear Tracks and Radiation Measurements, 14:237-241. https://doi.org/10.1016/1359-0189(88)90071-4

Heaney, L.R. 1991. A synopsis of climatic and vegetation changes in South East Asia. Climatic Change, 19:53-61. https://doi.org/10.1007/BF00142213

Kahlke, H.D. 1961. On the complex of the Stegodon-Ailuropoda fauna of Southern China and the chronological position of Gigantopithecus blacki V. Koenigswald. Vertebrata PalAsiatica, 6:83-108. 
Lisiecki, L.E. and Raymo, M.E. 2005. A Pliocene-Pleistocene stack of 57 globally distributed benthic $\delta^{18} \mathrm{O}$ records. Paleoceanography, 20:PA1003. https://doi.org/10.1029/ 2004PA001071

Louys, J. and Meijaard, E. 2010. Palaeoecology of Southeast Asian megafauna-bearing sites from the Pleistocene and a review of environmental changes in the region. Journal of Biogeography, 37(8):1432-1449. https://doi.org/10.1111/j.1365-2699.2010.02297.x

Marsh, R.E. 1999. Beta-gradient Isochrons Using Electron Paramagnetic Resonance: Towards a New Dating Method in Archaeology. MSc thesis, McMaster University.

Martin, J.E., Buffetaut, E., Naksri, W., Lauprasert, K., and Claude, J. 2012. Gavialis from the Pleistocene of Thailand and its relevance for drainage connections from India to Java. PLoS ONE, 7(9):e44541. https://doi.org/10.1371/journal.pone.0044541

National Academy of Sciences, 1983. Firewood Crops: Shrub and Tree Species for Energy Production, Vol. 2. The National Academy Press, Washington D.C. https://doi.org/10.17226/ 19480

Okada, M., Suganuma, Y., Haneda, Y., and Kazaoka, O. 2017. Paleomagnetic direction and paleointensity variations during the Matuyama-Brunhes polarity transition from a marine succession in the Chiba composite section of the Boso Peninsula, central Japan. Earth, Planets and Space, 69(1):45. https://doi.org/10.1186/s40623-017-0627-1

Pei, W.C., 1934. On the Carnivora from locality 1 of Choukoutien. Palaeontologia Sinica New Series C, 8(1):1-216.

Petit, J.R., Jouzel, J., Raynaud, D., Barkov, N.I., Barnola, J.-M., Basile, I., Bender, M., Chappellaz, J., Davis, M., Delaygue, G., Delmotte, M., Kotlyakov, V.M., Legrand, M., Lipenkov, V.Y., Lorius, C., Pépin, L., Ritz, C., Saltzman, E., and Stievenard, M. 1999. Climate and atmospheric history of the past 420,000 years from the Vostok ice core, Antarctica. Nature, 399:429-436. https://doi.org/10.1038/20859

Prescott, J.R. and Hutton, J.T. 1988. Cosmic ray and gamma ray dosimetry for TL and ESR. International Journal of Radiation Applications and Instrumentation. Part D. Nuclear Tracks and Radiation Measurements, 14(1-2):223-227. https://doi.org/10.1016/13590189(88)90069-6

Prescott, J.R. and Hutton, J.T. 1994. Cosmic ray contributions to dose rates for luminescence and ESR dating: Large depths and long-term time variations. Radiation Measurements, 23(2-3):497-500. https://doi.org/10.1016/1350-4487(94)90086-8

Shen, G., Gao, X., Gao, B., and Granger, D.E. 2009. Age of Zhoukoudian Homo erectus determined with ${ }^{26} \mathrm{Al} /{ }^{10} \mathrm{Be}$ burial dating. Nature, 458:198-200. https://doi.org/10.1038/ nature07741

Sheng, G.-L., Soubrier, J., Liu, J.-Y., Werdelin, L., Llamas, B., Thomson, V.A., Tuke, J., Wu, L.-J., Hou, X.-D., Chen, Q.-J., Lai, X.-L., and Cooper, A. 2014. Pleistocene Chinese cave hyenas and the recent Eurasian history of the spotted hyena, Crocuta crocuta. Molecular Ecology, 23(3):522-533. https://doi.org/10.1111/mec.12576

Singer, B.S., 2014. A Quaternary geomagnetic instability time scale. Quaternary Geochronology, 21(0):29-52. https://www.sciencedirect.com/science/article/pii/S1871101413000939

Songtham, W. and Chaodumrong, P. 2014. Cenozoic Era, p. 159-206. In Nuchanong, T., Chaodumrong, P., Luengingkasoot, M., Burrett, C., Techawan, S., Silakul, T., Stokes, R.B., Raksaskulwong, M., Chotikanatis, P., Kraikhong, C., Subtavewung, P., Assavapatcha, S., and Imsamut, S. (eds.), Geology of Thailand. Bureau of Geological Survey, Department of Mineral Resources, Bangkok, Thailand.

Stimpson, C.M., Lister, A., Parton, A., Clark-Balzan, L., Breeze, P.S., Drake, N.A., Groucutt, H.S., Jennings, R. , Scerri, E.M.L., White, T.S., Zahir, M., Duval, M., Grün, R., Al-Omari, A.., Al Murayyi, K.S.M., Zalmout, I.S., Mufarreh, Y.A., Memesh, A.M., and Petraglia, M.D. 2016. Middle Pleistocene vertebrate fossils from the Nefud Desert, Saudi Arabia: Implications for biogeography and palaeoecology. Quaternary Science Reviews, 143(Supplement C):13-36. https://doi.org/10.1016/j.quascirev.2016.05.016

Suraprasit, K., Jaeger, J.-J., Chaimanee, Y., Benammi, M., Chavasseau, O., Yamee, C., Tian, P., and Panha, S. 2015. A complete skull of Crocuta crocuta ultima indicates a late Middle Pleistocene age for the Khok Sung (northeastern Thailand) vertebrate fauna. Quaternary International, 374(Supplement C):34-45. https://doi.org/10.1016/j.quaint.2014.12.062 
Suraprasit, K., Jaeger, J.-J., Chaimanee, Y., Chavasseau, O., Yamee, C., Tian, P., and Panha, S. 2016. The Middle Pleistocene vertebrate fauna from Khok Sung (Nakhon Ratchasima, Thailand): biochronological and paleobiogeographical implications. ZooKeys, 613:1-157. https://doi.org/10.3897/zookeys.613.8309

Suraprasit, K., Bocherens, H., Chaimanee, Y., Panha, S., and Jaeger, J.-J. 2018. Late Middle Pleistocene ecology and climate in Northeastern Thailand inferred from the stable isotope analysis of Khok Sung herbivore tooth enamel and the land mammal cenogram. Quaternary Science Reviews, 193:24-42. https://www.sciencedirect.com/science/article/pii/ S0277379117308247

Suraprasit, K., Jongautchariyakul S., Yamee, C., Potichaiya, C., and Bocherens, H. 2019. New fossil and isotope evidence for the Pleistocene zoogeographic transition and hypothesized savanna corridor in Peninsular Thailand. Quaternary Science Reviews, 221:105861. https:// doi.org/10.1016/j.quascirev.2019.105861

Tougard, C. 2001. Biogeography and migration routes of large mammal faunas in South-East Asiaduring the Late Middle Pleistocene: focus on the fossil and extant faunas from Thailand. Palaeogeography, Palaeoclimatology, Palaeoecology, 168:337-358. https://doi.org/10.1016/ S0031-0182(00)00243-1

Tougard, C., Jaeger, J.-J., Chaimanee, Y., Suteethorn, V., and Triamwichanon, S. 1998. Discovery of a Homo sp. tooth associated with a mammalian cave fauna of Late Middle Pleistocene age, Northern Thailand. Journal of Human Evolution, 35:47-54. https://doi.org/ 10.1006/jhev.1998.0221

Wang, Y., Cheng, H., Edwards, R.L., Kong, X., Shao, X., Chen, S., Wu, J., Jiang, X., Wang, X., and An, Z. 2008. Millennial- and orbital-scale changes in the East Asian monsoon over the past 224,000 years. Nature, 451:1090-1093. https://doi.org/10.1038/nature06692

Westaway, K.E., Morwood, M.J., Roberts, R.G., Rokus, A.D., Zhao, J.-X., Storm, P., Aziz, F., van den Bergh, G., Hadi, P., Jatmiko, and de Vos, J. 2007. Age and biostratigraphic significance of the Punung Rainforest Fauna, East Java, Indonesia, and implications for Pongo and Homo. Journal of Human Evolution, 53:709-717. https://www.sciencedirect.com/science/ article/pii/S0047248407001133

Zeitoun, V., Lenoble, A., Laudet, F., Thompson, J., Rink W. J., Mally J.-B., and Chinnawut, W. 2010. The Cave of the Monk (Ban Fa Suai, Chiang Dao wild life sanctuary, northern Thailand). Quaternary International, 220:160-173. https://doi.org/10.1016/ j.quaint.2009.11.022

Zeitoun,V., Chinnawut, W., Lenoble, A., Bochaton C., Burdette, K., Thompson, J., Mally J.-B., Frère, S., Debruyne, R., Antoine P.-O., Rink W.J., and Autrakulvit, P. In press. Dating, stratigraphy and taphonomy of the Pleistocene site of Ban Fa Suai II (Northern Thailand): Contributions to the study of paleobiodiversity in Southeast Asia. Annales de Paléontologie. https://doi.org/10.1016/j.annpal.2019.03.005 


\section{SUPPLEMENTARY MATERIAL}

Direct ESR dating of the Pleistocene vertebrate assemblage from Khok Sung locality, Nakhon Ratchasima Province, Northeast Thailand

TABLE S1. Lithologic descriptions of the Khok Sung sand pit in Nakhon Ratchasima Province, Northeastern Thailand.

\begin{tabular}{|c|c|c|c|}
\hline $\begin{array}{l}\text { Lithostratigraphic } \\
\text { unit }\end{array}$ & $\begin{array}{l}\text { Thickness } \\
\text { (cm) }\end{array}$ & Sedimentary structure & $\begin{array}{c}\text { Sedimentary composition } \\
\text { (e.g., color, texture, sorting, roundness) }\end{array}$ \\
\hline A & $10-15$ & Homogeneous bedding & $\begin{array}{l}\text { Dark brownish-silty mud, homogeneous texture, very poor } \\
\text { sorting, abundant plant remains (root, root traces, wood } \\
\text { fragments). }\end{array}$ \\
\hline B & $80-100$ & Horizontal bedding & $\begin{array}{l}\text { Brownish-silty mud, very poor sorting, plant remains (root } \\
\text { and wood fragments) }\end{array}$ \\
\hline C & $100-150$ & Slickenside & $\begin{array}{l}\text { Brownish yellow to dark brownish color, fine-sandy mud } \\
\text { with humic substances, very poor sorting, black Mn and } \\
\text { Fe isolites, carbonate concretions and plant remains } \\
\text { (about } 20 \% \text { ). }\end{array}$ \\
\hline $\mathrm{D}$ & $120-220$ & $\begin{array}{l}\text { Fining upward sequence, } \\
\text { trough and tabular cross- } \\
\text { lamination }\end{array}$ & $\begin{array}{l}\text { Light brownish to dark brownish color, fine to coarse sand, } \\
\text { well sorting, sub-rounded to rounded shape, plant remains } \\
\text { (root and wood fragments). }\end{array}$ \\
\hline$E$ & $80-100$ & $\begin{array}{l}\text { Fining upward sequence, } \\
\text { high angle planar and } \\
\text { trough cross-lamination }\end{array}$ & $\begin{array}{l}\text { Light pinkish gray to dark gray color, fine to medium sand, } \\
\text { moderate to well sorting, subangular to subrounded } \\
\text { shape, gray carbonate mud clasts, mud lenses, abundant } \\
\text { petrified wood fragments and trunks. }\end{array}$ \\
\hline $\mathrm{F}$ & $50-70$ & $\begin{array}{l}\text { Horizontal bedding, fining } \\
\text { upward sequence }\end{array}$ & $\begin{array}{l}\text { Gray to dark gray color, coarse to very coarse sand and } \\
\text { matrix-supported gravel (quartz and silicified rocky } \\
\text { grains), well sorting, sub-rounded to rounded shape, } \\
\text { layered silty-muddy lenses interbedded at the upper part, } \\
\text { plant (leaves and seeds at the silty mud layers) and } \\
\text { vertebrate remains (abundant at the lowermost part). }\end{array}$ \\
\hline G & $10-20$ & $\begin{array}{l}\text { Horizontal bedding, } \\
\text { coarsening upward } \\
\text { sequence }\end{array}$ & $\begin{array}{l}\text { Gray to dark gray color, grained supported gravel (rich } \\
\text { calcareous mud clasts, slightly quartz and silicified rocky } \\
\text { grains, } 1-3 \mathrm{~cm} \text { in sizes), very poor sorting, sub-angular to } \\
\text { sub-rounded shape. }\end{array}$ \\
\hline $\mathrm{H}$ & $80-100$ & $\begin{array}{l}\text { Horizontal bedding, fining } \\
\text { upward sequence }\end{array}$ & $\begin{array}{l}\text { Dark gray silty mud, moderate to well sorting, interbedded } \\
\text { fine-sandy lenses, plant remains (abundant at the upper } \\
\text { part). }\end{array}$ \\
\hline 1 & $25-80$ & $\begin{array}{l}\text { Fining upward sequence } \\
\text { with underlying sharp } \\
\text { contact, trough cross- } \\
\text { lamination }\end{array}$ & $\begin{array}{l}\text { Pinkish gray fine to medium sand, well sorting, sub- } \\
\text { angular to sub-rounded shape, and gray to dark gray } \\
\text { grained supported gravel at the lowermost part (slightly } \\
\text { calcareous mud clasts, abundant quartz and silicified } \\
\text { rocky grains, } 1-3 \mathrm{~cm} \text { in sizes), poor to very poor sorting, } \\
\text { sub-angular to sub-rounded shape. }\end{array}$ \\
\hline
\end{tabular}


TABLE S2. ESR data collected from the six samples. Fitting results derived from the use of Dmax $=4019 \mathrm{~Gy}$ are given for comparison. Note that the $D_{E}$ errors used for age calculation includes an additional $2.3 \%$ error on the gamma source dose rate (Tables 3 and 5).

\begin{tabular}{cccccccccc}
\hline Sample & $\begin{array}{c}\mathbf{D}_{\max } \\
(\mathbf{G y})\end{array}$ & $\begin{array}{c}\mathbf{D}_{\mathrm{E}} \text { value } \\
(\mathbf{G y})\end{array}$ & $\mathbf{D}_{\max } / \mathbf{D}_{\mathrm{E}}$ & $\begin{array}{c}\mathbf{A d j} . \\
\text { r-Square }\end{array}$ & $\begin{array}{c}\mathbf{D}_{\max } \\
(\mathbf{G y})\end{array}$ & $\begin{array}{c}\mathbf{D}_{\mathrm{E}} \text { value } \\
(\mathbf{G y})\end{array}$ & $\mathbf{D}_{\max } / \mathbf{D}_{\mathrm{E}}$ & $\begin{array}{c}\mathbf{A d j} . \\
\text { r-Square }\end{array}$ & $\begin{array}{c}\mathbf{D}_{\mathrm{E}} \\
\text { ratio }\end{array}$ \\
\hline 3545 & 642 & $73.2 \pm 3.9$ & 8.8 & 0.9972 & 4019 & $72.0 \pm 1.8$ & 55.8 & 0.9987 & 1.02 \\
$3546 \mathrm{~A}$ & 642 & $99.4 \pm 3.6$ & 6.5 & 0.9988 & 4019 & $101.7 \pm 1.7$ & 39.5 & 0.9994 & 0.98 \\
$3546 \mathrm{~B}$ & 1005 & $131.5 \pm 4.1$ & 7.6 & 0.9990 & 4019 & $136.6 \pm 2.8$ & 29.4 & 0.9991 & 0.96 \\
3547 & 1005 & $135.7 \pm 5.5$ & 7.4 & 0.9983 & 4019 & $143.1 \pm 3.4$ & 28.1 & 0.9988 & 0.95 \\
3548 & 2009 & $313.0 \pm 11.4$ & 6.4 & 0.9983 & 4019 & $313.0 \pm 7.7$ & 12.8 & 0.9988 & 1.00 \\
\hline 3549 & 1005 & $124.0 \pm 4.2$ & 8.1 & 0.9988 & 4019 & $132.6 \pm 3.1$ & 30.4 & 0.9988 & 0.94 \\
\hline
\end{tabular}

TABLE S3. Initial combined US-ESR dating results obtained from using a gamma dose rate derived from mean concentration values of the 13 sediment samples.

\begin{tabular}{|c|c|c|c|c|c|c|}
\hline SAMPLE & 3545 & 3546A & 3546B & 3547 & 3548 & 3549 \\
\hline Internal dose rate $(\mu \mathrm{Gy} / \mathrm{a})$ & $110 \pm 35$ & $12 \pm 5$ & $11 \pm 4$ & $18 \pm 7$ & $80 \pm 49$ & $44 \pm 13$ \\
\hline $\begin{array}{l}\text { Beta dose rate, tissue } 1 \\
\text { (dentine) }(\mu \mathrm{Gy} / \mathrm{a})\end{array}$ & $39 \pm 11$ & $3 \pm 0$ & $2 \pm 0$ & $92 \pm 31$ & $884 \pm 351$ & $151 \pm 31$ \\
\hline $\begin{array}{l}\text { Beta dose rate, sediment or } \\
\text { tissue } 2(\mu \mathrm{G} / \mathrm{a})\end{array}$ & $13 \pm 3$ & $44 \pm 9$ & $224 \pm 63$ & $61 \pm 17$ & $54 \pm 13$ & $61 \pm 12$ \\
\hline Gamma dose rate $(\mu \mathrm{Gy} / \mathrm{a})$ & $470 \pm 79$ & $470 \pm 79$ & $470 \pm 79$ & $470 \pm 79$ & $470 \pm 79$ & $470 \pm 79$ \\
\hline Cosmic dose rate $(\mu \mathrm{Gy} / \mathrm{a})$ & $109 \pm 12$ & $109 \pm 12$ & $109 \pm 12$ & $109 \pm 12$ & $109 \pm 12$ & $109 \pm 12$ \\
\hline Total dose rate $(\mu \mathrm{Gy} / \mathrm{a})$ & $742 \pm 87$ & $639 \pm 79$ & $816 \pm 101$ & $751 \pm 85$ & $1598 \pm 363$ & $836 \pm 86$ \\
\hline p-enamel & -0.64 & 0.97 & 1.07 & 0.89 & 0.28 & 0.81 \\
\hline p-tissue 1 (dentine) & 0.00 & 1.66 & 3.36 & 2.09 & 0.13 & 2.32 \\
\hline p-tissue 2 & - & - & 3.01 & - & - & - \\
\hline Combined US-ESR age (ka) & $98+16-12$ & $155+26-18$ & $161+24-21$ & $180+26-19$ & $195+51-32$ & $148+19-14$ \\
\hline $\begin{array}{l}\text { Combined CSUS-ESR age } \\
\text { (ka) }\end{array}$ & $105 \pm 15$ & $156 \pm 21$ & $176 \pm 25$ & $202 \pm 27$ & $280 \pm 41$ & $175 \pm 23$ \\
\hline
\end{tabular}



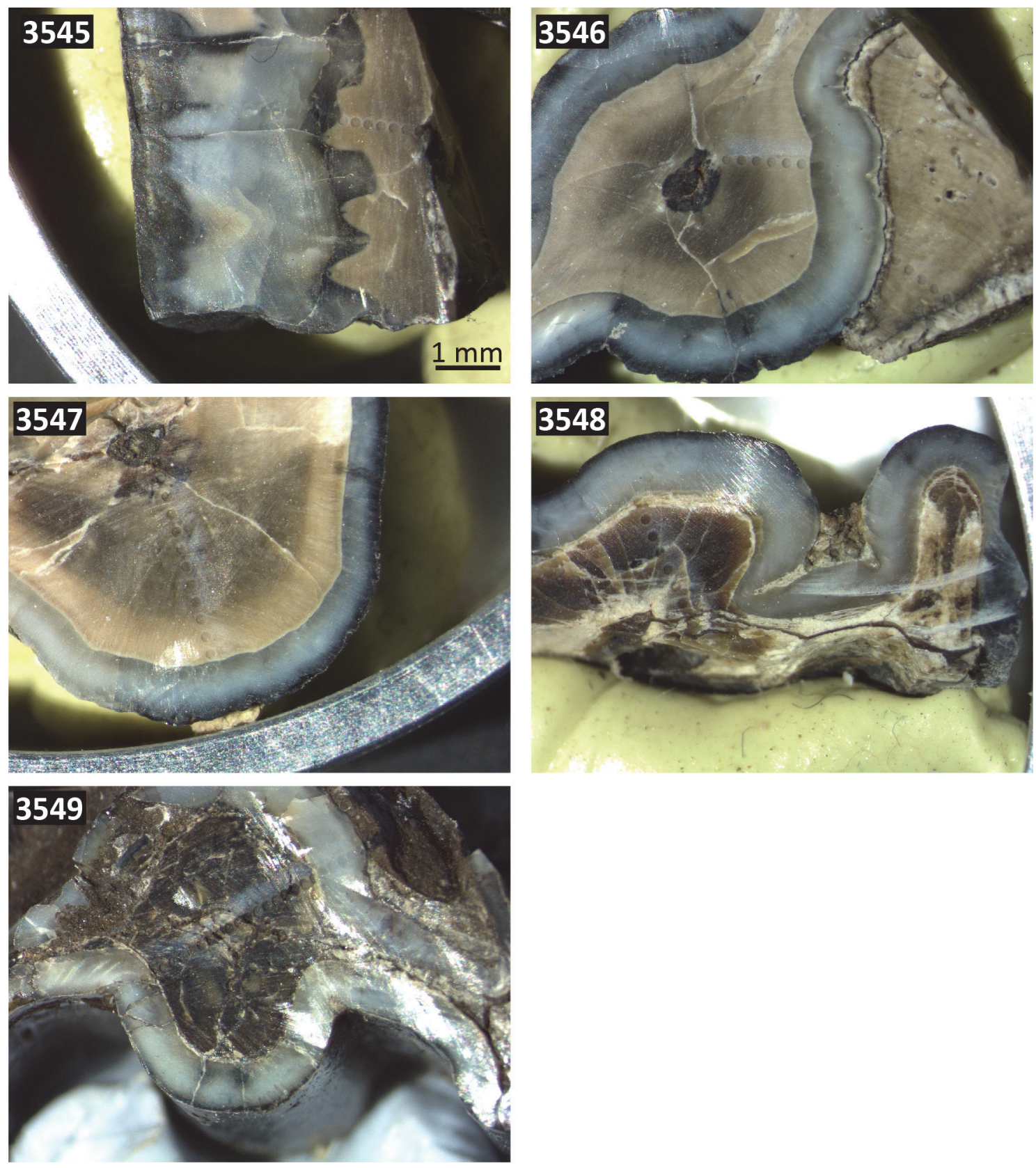

FIGURE S1. Pictures of the cross-sections from the five fossil teeth analysed by LA-ICP-MS analyses (ablation spots are visible). The same scale applies to all pictures. 

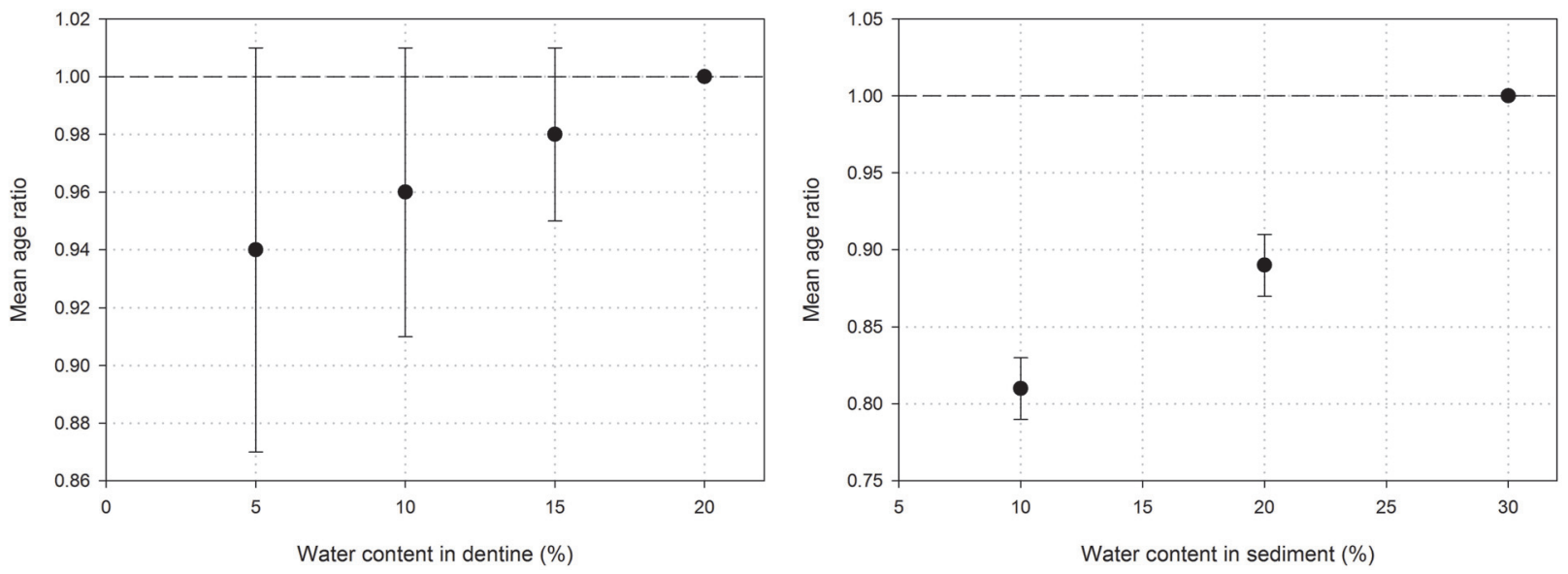

FIGURE S2. Impact of the water content on the calculated US-ESR ages. Age results obtained for $20 \%$ water in dentine and $30 \%$ water in sediment are taken as references. Simulations were performed for the 6 samples with 5, 10, $15 \%$ water in dentine. Mean value and associated standard deviation (vertical error bar) were extracted and compared with reference values. A similar procedure was employed for the water content in sediment (simulations performed with 10 and $20 \%$ water). 